\title{
Hydrothermal signatures in the southern Okinawa Trough detected by the sequential extraction of settling particles
}

\author{
Shih-Chieh $\mathrm{Hsu}^{\mathrm{a}, *}$, Fei-Jan Lin ${ }^{\mathrm{b}}$, Woei-Lih Jeng ${ }^{\mathrm{b}}$, \\ Yu-chia Chung ${ }^{\mathrm{c}}$, Li-Min Shaw ${ }^{\mathrm{b}}$ \\ ${ }^{a}$ Institute of Earth Sciences, Academia Sinica, Taipei, Taiwan, ROC \\ ${ }^{\mathrm{b}}$ Institute of Oceanography, National Taiwan University, Taipei, Taiwan, ROC \\ ${ }^{\mathrm{c}}$ Institute of Marine Geology and Chemistry, National Sun Yat-sen University, Kaohsiung, Taiwan, ROC
}

Received 1 October 2001; received in revised form 20 March 2003; accepted 3 June 2003

\begin{abstract}
Sediment trap samples collected over 6 months at two depths within the southern Okinawa Trough (SOT) have been analyzed for phase associations of $\mathrm{Al}, \mathrm{Fe}, \mathrm{Mn}$ and $\mathrm{Pb}$ by six-stage sequential extraction (SSSE). The deeper samples are characterized by the presence of hydrothermal constituents (such as $\mathrm{Mn}$ and likely $\mathrm{Fe}$ and $\mathrm{Pb}$ ), while shallower samples are representative of background-settling particles originating from laterally transported sediments. These results suggest that the extraction scheme is appropriate for detecting particles affected by hydrothermal emanations.

Analytical results show that shallower and deeper samples have similar total Al contents and total Fe contents; by contrast, $\mathrm{Mn}$ and $\mathrm{Pb}$ are 1.7- and 1.6-fold higher in the deeper samples than in the shallower samples, respectively. Additionally, the two depths have almost the same phase associations for $\mathrm{Al}$ and $\mathrm{Fe}$, but largely different phase associations for $\mathrm{Mn}$ and $\mathrm{Pb}$. Compositional differences in $\mathrm{Mn}$ and $\mathrm{Pb}$ between the two depths depend essentially on the relative abundance of the fresh oxide fraction. The observed phase association suggests that $\mathrm{Mn}$ anomalies in the deeper samples are derived preferentially from adsorptive oxidation of dissolved hydrothermal Mn onto settling particles and/or incorporation of very fine Mn-enriched hydrothermal precipitates within settling particles. $\mathrm{Pb}$ anomalies in the deeper samples imply either a similar hydrothermal origin and/or scavenging of dissolved $\mathrm{Pb}$ from ambient water by newly formed oxides/hydroxides. The constant concentration of Mn within the deeper samples may reflect phase equilibrium between dissolved Mn and settling particles. Hydrothermally derived fluxes, defined as the fraction from hydrothermal contributions and/or indirectly by processes related to hydrothermal activities, have been estimated at $7.0 \pm 3.1 \mathrm{mg} / \mathrm{m}^{2} /$ day for $\mathrm{Fe}, 2.3 \pm 1.0 \mathrm{mg} / \mathrm{m}^{2} /$ day for $\mathrm{Mn}$ and $0.07 \pm 0.03 \mathrm{mg} / \mathrm{m}^{2} / \mathrm{day}$ for Pb. These fluxes are higher than those found at other hydrothermal systems owing to high loads of settling and suspended particles. (C) 2003 Elsevier B.V. All rights reserved.
\end{abstract}

Keywords: Six-stage sequential extraction; Phase association; Hydrothermal plume; Mn anomaly; The southern Okinawa Trough

\footnotetext{
* Corresponding author. Tel.: +886-2-27839910x252; fax: $+886-2-27833584$.

E-mail address: schsu@earth.sinica.edu.tw (S.-C. Hsu).
}

\section{Introduction}

The Okinawa Trough (OT) is an active curved backarc basin located behind the Ryukyu trench-arc system (Fig. 1A). It extends from the southwest of 
(A)

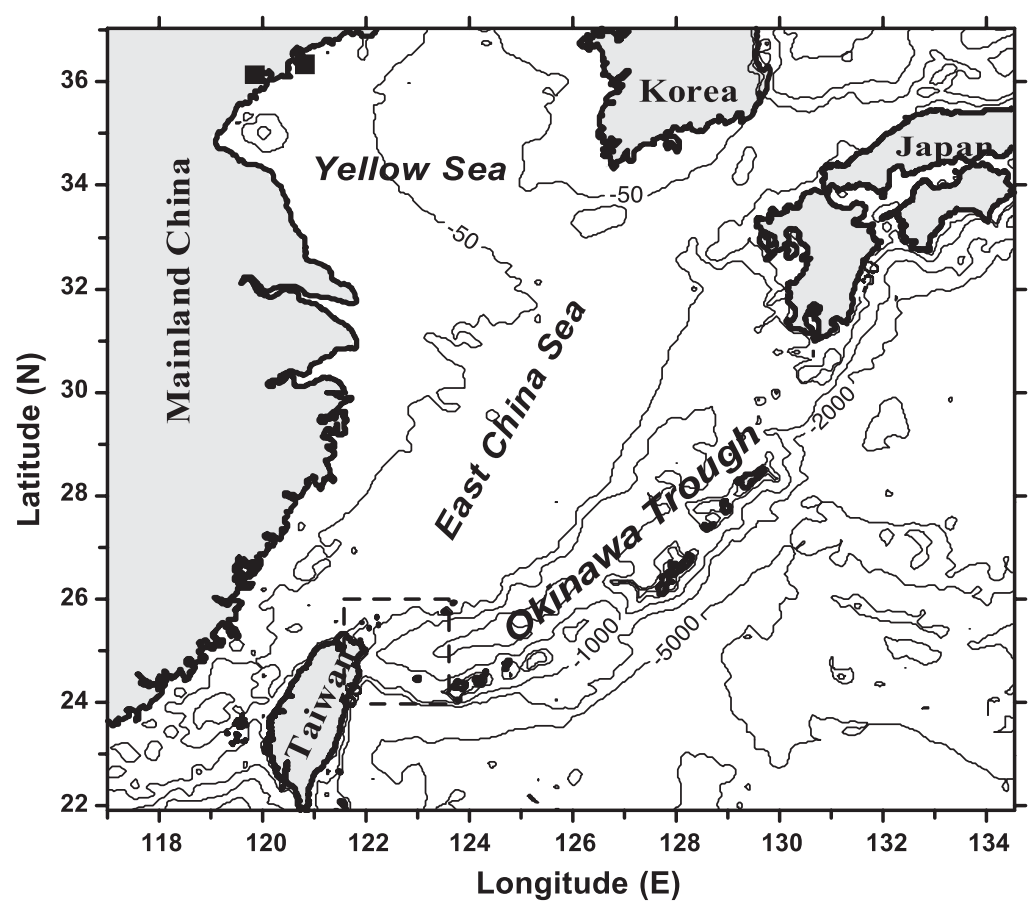

(B)

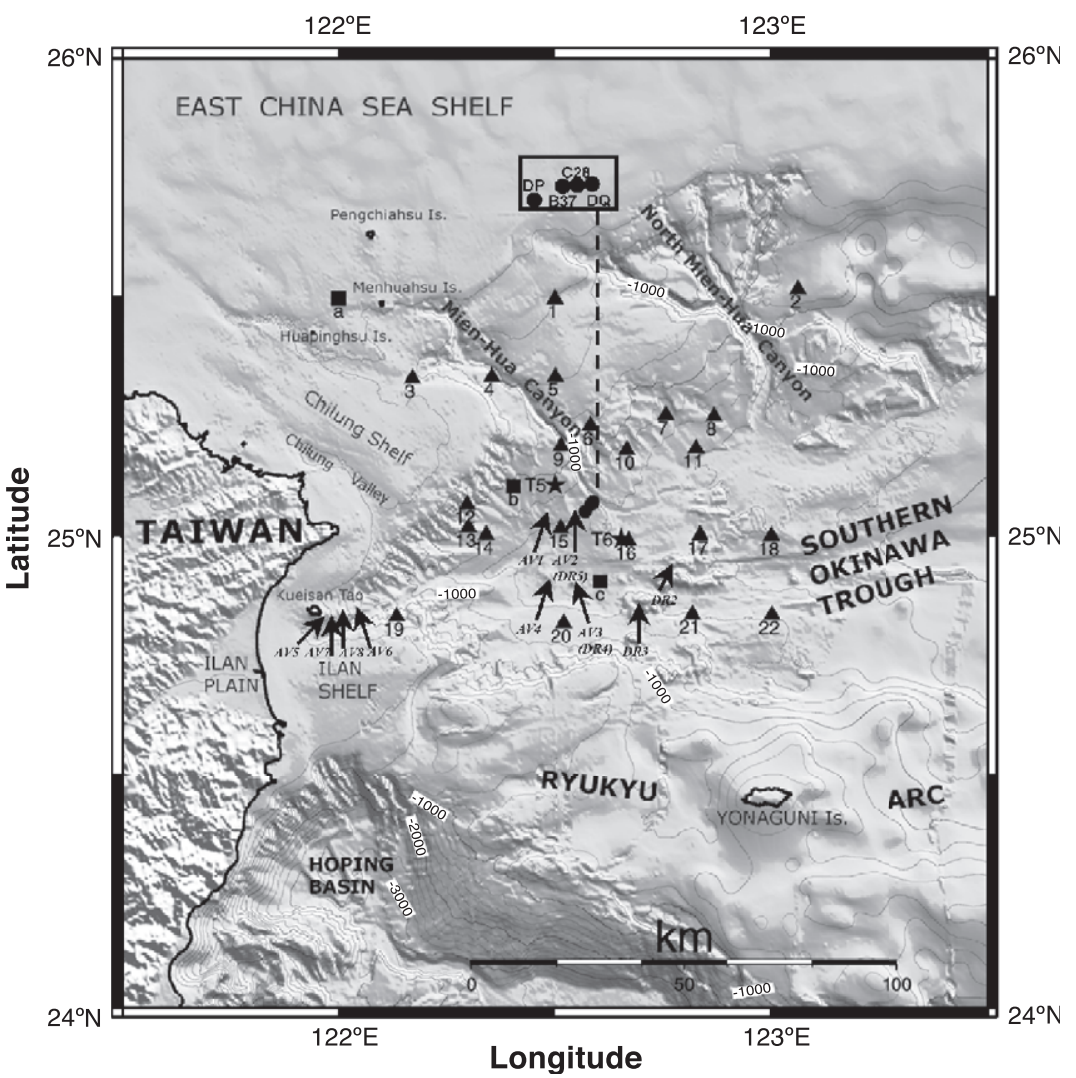


Kyushu, Japan to the Ilan Plain in northern Taiwan. Numerous normal faults and grabens exist along the axis of the basin. Several hypotheses or models to describe the formation and evolution of this marginal backarc basin have been proposed (Lee et al., 1980; Sibuet et al., 1987, 1995, 1998; Letouzey and Kimura, 1986). Basin opening commenced during the Miocene, corresponding to the collision between the Eurasian and Philippine Sea plates, and continues today most intensively in the middle and southern OT (SOT) (Lee et al., 1980; Sibuet et al., 1995). The maximum depth of the SOT is $2270 \mathrm{~m}$, its width is $60-100 \mathrm{~km}$ and the crustal thickness is $\sim 15 \mathrm{~km}$ (Lee et al., 1980). High heat flows have been measured in the SOT and igneous ridges or intrusions have been observed throughout sediments (Lee et al., 1980; Lu et al., 1981; Yamano et al., 1989; Sibuet et al., 1995; Shyu and Liu, 2001). The SOT is currently in a continental rifting stage; the oceanic domain has likely developed and is limited to volcanic ridges in the axial portion of the trough (Hirata et al., 1991). In addition, thick sediments of about $1-3 \mathrm{~km}$ are deposited on the seafloor.

Several international expeditions have recently integrated efforts to study the SOT (Taiwan-French: Liu et al., 1998; Sibuet et al., 1998; Taiwan-Japan: Chung et al., 1998; Lee et al., 1998, 2000; Chan et al., 2000). The regional seafloor morphology was defined using high-quality bathymetry during the FrenchTaiwanese joint arc-continental collision in Taiwan cruise of 1996 (Liu et al., 1998; Sibuet et al., 1998). Volcanic analogs including seamounts and hydrothermal vents and chimneys located along backarc basin seafloor have been identified (Fig. 1B). In August 2000, exploration of hydrothermal vents, approximately $90 \mathrm{~km}$ from eastern Kueisan-Tao island (Fig. 1B), using the manned deep-sea research submersible Shinkai 6500 (Japan Marine Science and Technology Center) was undertaken in the hydrothermal field of DR3. Several discernible phenomena were discovered (Lee et al., 1998, 2000; Chan et al., 2000), but detailed results have not yet been published. For instance, preliminary results showed: (1) chimney heights ranging from 1 to $10 \mathrm{~m}$, (2) temperatures of hydrothermal emanations $\geq 170{ }^{\circ} \mathrm{C}$, (3) $\mathrm{pH}$ values of hydrothermal emanations around 4.5 and (4) extensive colonies of organisms (specially Shinkaia crosnieri) clinging to the chimneys (Lee, 2002). In addition, echo sounder (Simrad EK500) commonly imaged bubblelike signals rising from the sea floor, suggesting hydrothermal venting of a gas phase (Lee, personal communication).

For the SOT, these unique environmental conditions such as the seafloor being developed on the continental crust and overlain by thick sediments could be expected to substantially influence the compositions of hydrothermal fluids and even magma. For example, the interaction of hydrothermal fluids with sediments could cause enrichments of $\mathrm{CO}_{2}$ and $\mathrm{CH}_{4}$ gases (Welhan and Lupton, 1987) and boron (You et al., 1994). Tsunogai et al. (1994) measured lower He isotopic ratios of hydrothermal fluids from the middle OT than MORB and attributed this to minor contamination by crustal radiogenic He from the thin continental crust. Ishibashi and Urabe (1995) have compiled and compared the specific nature of hydrothermal activities and fluids from arc-backarc systems in the western Pacific. Their results show that $\mathrm{Pb}$ abundances of hydrothermally derived massive sulfides from the middle OT are around $15 \%$, much higher than those of other arc-backarc sites. Additionally, the Fe concentration in hydrothermal fluids is very low, $21 \mu \mathrm{M}$, compared to the $\mathrm{Mn}$ concentration, $370 \mu \mathrm{M}$. Almost all published data on the chemical compositions of hydrothermal fluids from the OT were from the northern and middle parts of the OT. Apart from the data of Chen (1994) who detected abnormally high dissolved $\mathrm{CH}_{4}(550 \mathrm{nM})$ in the bottom water off northeastern Taiwan, up to the present there has been no other chemical data of hydrothermal fluids reported for the SOT.

Fig. 1. (A) Regional map of the study area. (B) Sites of trap samples (stations T5 and T6, $\star$ ), seawater (stations a, b and c for analyzing metals, 口; stations DP, B37, C28 and DQ for analyzing methane, $\bullet$ ) and sediments (stations 1-22, $\mathbf{\Delta}$ ) studied in this work. The exact location data are given in the text. Inset is a regional map (see the following page). The high-quality digital bathymetric map is provided by the National Center for Ocean Research, Taiwan. Numerous submarine volcanoes and/or their analogs such as seamounts, hydrothermal vents and chimneys are identified (arrows with numbers). Site AV\#2 (DR\#5) is the likely source of the hydrothermal plume anomalies discussed in this text. Kueisan Tao Island is situated at $10 \mathrm{~km}$ off eastern Taiwan. 
Twenty-four time-series sediment trap samples were collected over 6 months at two depths (740 and $1340 \mathrm{~m}$ ) within the SOT from a site known to be influenced by a seafloor hydrothermal emanation of $\mathrm{CH}_{4}$ (Chen, 1994). They have been analyzed for total elemental composition and particulate phase associations of selected metals by total digestion and six-stage sequential extraction (SSSE), respectively. Sequential extractions have been utilized in a variety of marine environments including deposited sediments (Rajendran et al., 1992; O'Reilly Wiese et al., 1997), manganese nodules or encrustations (Aplin and

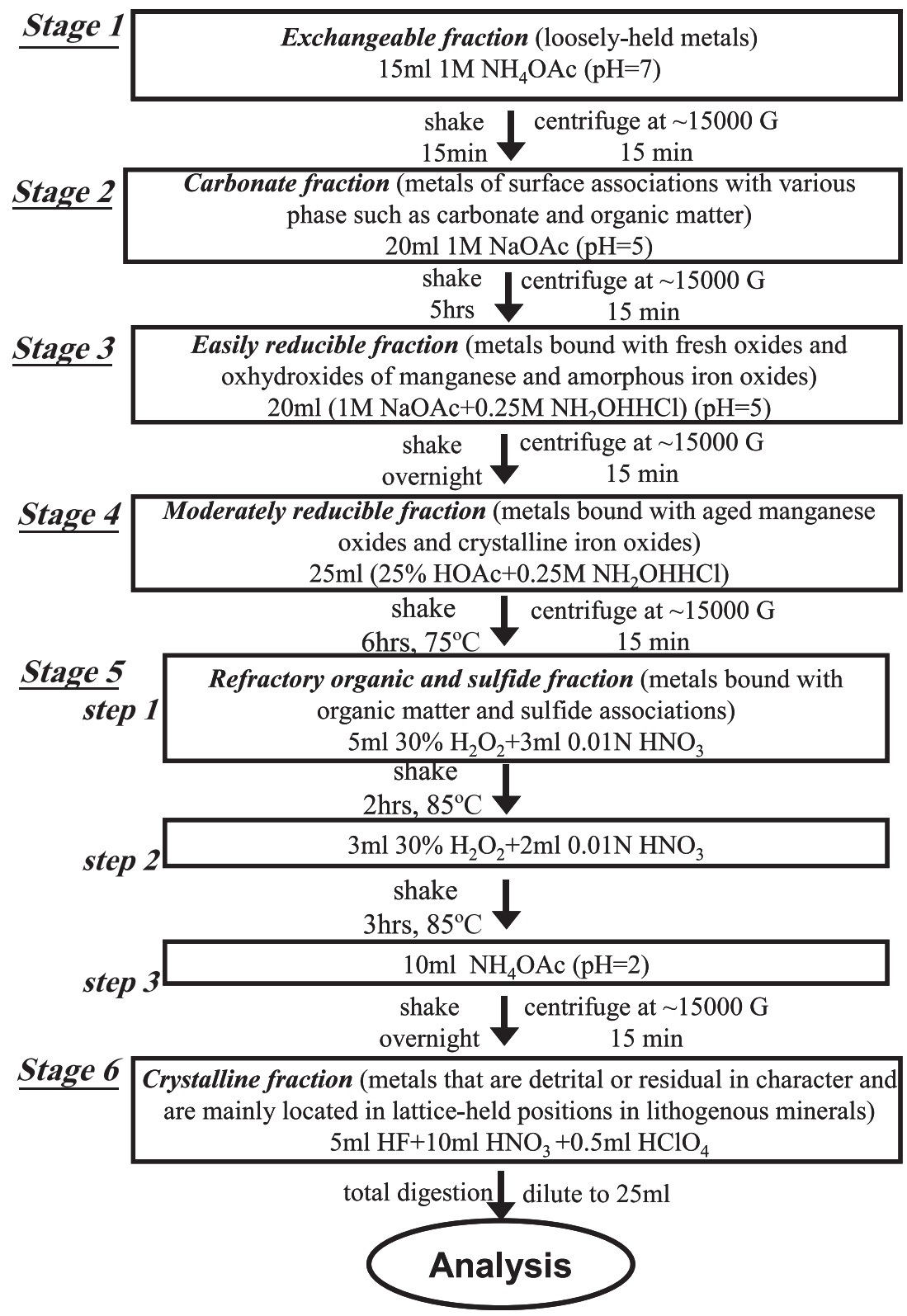

Fig. 2. Scheme describing operational definitions of each association, reagents and optimized conditions used in the six-stage sequential extraction scheme, modified from Chester et al. (1988, 1994). 
Cronan, 1985), suspended matter (Elbaz-Poulichet et al., 1984; Chester et al., 1988; 1994) and settling particles (Noriki et al., 1997). Results from sequential extraction provide valuable insights into elemental mobility and thus biogeochemical behaviors of elements within their existing environments or mediums (Bernhard et al., 1986; Landner, 1987; Bryan and Langston, 1992). Landing and Bruland (1987) extensively illustrated the processes governing the partitioning and cycling behavior of $\mathrm{Fe}$ and $\mathrm{Mn}$ in the seas from extraction data. With regard to research goals, experimental costs, operational convenience, etc., analysts may choose varying stages of extraction ranging from two to seven or more (Tessier et al., 1979; El Ghobary and Latouche, 1986; Skei et al., 1988; Shaw et al., 1990; O’Reilly Wiese et al., 1997).

SSSE was chosen for use in our study. The operationally defined host associations for selected metals and the SSSE extraction stages (in order of increasing refractory nature) are exchangeable, carbonate, easily reducible, moderately reducible, refractory organic and sulfide, and crystalline (Fig. 2). SSSE was used to determine the phase associations of $\mathrm{Mn}$ (an element enriched in hydrothermal solutions), $\mathrm{Pb}$ (a particle-reactive and hydrothermally enriched element), $\mathrm{Al}$ (a lithogenic indicator element) and $\mathrm{Fe}$ (of terrestrial and hydrothermal origin). The purposes of this work were (1) to partially characterize the compositions of hydrothermal plumes in this backarc basin; (2) to determine the speciation signatures of selected metals and their similarities and dissimilarities between the two depths; (3) to examine the removal processes and host phases for certain metals enhanced by hydrothermal contributions (i.e. $\mathrm{Mn}$ and likely $\mathrm{Pb}$ ); and (4) to evaluate the ability of SSSE to discriminate hydrothermal chemical signatures for selected metals within settling particles. Surface sediments and sediment cores were also analyzed for a variety of metals to evaluate the impact of hydrothermal activities on the chemical compositions of surface sediments and/or the contribution of diagenetic sources of dissolved $\mathrm{Mn}(\mathrm{DMn})$ to the observed Mn enrichment of settling particles. Finally, seawater was analyzed for dissolved metals (particularly $\mathrm{Mn}$ ) to identify possible diagenetic and hydrothermal sources of metals to the particles collected in this study. This study provides valuable insights into the chemical nature of backarc basin hydrothermal emanations, which are poorly known and possibly significant to seawater trace metal pools.

\section{Materials and experiments}

\subsection{Sampling}

In an area assumed to be influenced by hydrothermal emanations, settling particulates were collected for 6 months $(11 / 14 / 1994$ to $5 / 12 / 1995)$ at 740 and $1340 \mathrm{~m}$ from sediment trap mooring array $\mathrm{T} 6$ $\left(24^{\circ} 59.63^{\prime} \mathrm{N}, 122^{\circ} 39.26^{\prime} \mathrm{E}\right.$; bottom depth $\left.1440 \mathrm{~m}\right)$ in the SOT off northeastern Taiwan (Fig. 1B). For comparison, settling particles were collected in an area without hydrothermal impact from three depths from sediment trap mooring array T5 (5/5-9/1/1994 at $25^{\circ} 06.45^{\prime} \mathrm{N}, 122^{\circ} 30.06^{\prime} \mathrm{E}$; bottom depth $1060 \mathrm{~m}$ ), which was deployed at a transit position, between Mien-hua Canyon and the SOT (Fig. 1B). Frenchmade PPS 3/3 (Piege a Particules Sequentiel, Model $3 / 3$, a modified version of the PPS 3 used earlier in the French ECOMARGE program) sediment traps (Heussner et al., 1990) equipped with 12 sampling cups were employed. Cylindrical traps have an aspect ratio of 2.5 , a collection area of $0.125 \mathrm{~m}^{2}$ and a cone at the lower end to funnel the particles into a cup. The collection duration of each cup was 15 days for T6 and 10 days for T5. Current meters were attached at intermediate depths of any two traps; these results have been published elsewhere (Chung and Hung, 2000). Details of sampling and sample pre-treatments have been given in Chung and Hung (2000). In addition, profiles exhibiting particulate and dissolved $\mathrm{Mn}$ and $\mathrm{Pb}$ anomalies in the regional water column also demonstrated hydrothermal venting. Seawater samples were collected from a station (station c at $24^{\circ} 54.29^{\prime} \mathrm{N}, 122^{\circ} 36.25^{\prime} \mathrm{E}$ with bottom depth 1523 m) near the T6 trap deployment site in August 1994. There were two other $\mathrm{Mn}$ and $\mathrm{Pb}$ profiles: one on the continental shelf (station a at $25^{\circ} 29.90^{\prime} \mathrm{N}$, $122^{\circ} 00.05^{\prime} \mathrm{E}$ with bottom depth $119 \mathrm{~m}$ ) and one on the slope (station b at $25^{\circ} 06.28^{\prime} \mathrm{N}, 122^{\circ} 24.30^{\prime} \mathrm{E}$ with bottom depth $1080 \mathrm{~m}$ ) (Fig. 1B); they were used to evaluate the diagenetic contributions to Mn concentrations in the T6 deeper samples or the Mn plume in the SOT deep water. Seawater was collected using 20 liter GO-FLO PTFE-coated bottles on a CTD rosette, 
and was taken from the water column at varying depths. About $20 \sim 40$ liters of seawater were pressure-filtered through a pre-cleaned, pre-weighed 142 $\mathrm{mm}-0.4 \mu \mathrm{m}$ Nuclepore polycarbonate filter. A liter of filtrate was stored in acid-precleaned 1-1 polypropylene bottles (Nalgene) and acidified to $\mathrm{pH}<2$ (final $\mathrm{HNO}_{3}$ concentration around $0.03 \mathrm{M}$ ) with Suprapur $\mathrm{HNO}_{3}$ (Merck) for subsequent analysis of dissolved trace metals in a land-based laboratory. Particulateladen filters were stored in plastic petri dishes. Seawater and particulate samples were kept in a refrigerator and a desiccator, respectively, until analysis. In addition, four profiles of dissolved $\mathrm{CH}_{4}$ collected in September 1993 (station B37 at $25^{\circ} 04.05^{\prime} \mathrm{N}$, $122^{\circ} 35.02^{\prime} \mathrm{E}$ with bottom depth $1340 \mathrm{~m}$ ) and October 1993 (station $\mathrm{C} 28$ at $25^{\circ} 04.36^{\prime} \mathrm{N}, 122^{\circ} 35.30^{\prime} \mathrm{E}$ with bottom depth $1397 \mathrm{~m}$ ) and March 1994 (two stations, station DP at $25^{\circ} 03.12^{\prime} \mathrm{N}, 122^{\circ} 34.23^{\prime} \mathrm{E}$ with bottom depth of $1283 \mathrm{~m}$ and station DQ at $25^{\circ} 04.37^{\prime} \mathrm{N}$, $122^{\circ} 35.32^{\prime} \mathrm{E}$ with bottom depth $1395 \mathrm{~m}$ ) are taken from Chen (1994). At all of the sampling sites (sediment traps, T6; metals, station C; dissolved methane, stations DP, DQ, B37 and C28) located

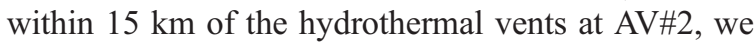
found evidence for a hydrothermal plume. It will be shown that the prevailing southeastern deep flow at around $1200 \mathrm{~m}$ depth could disperse hydrothermal emanations downstream from the possible hydrothermal vent $(\mathrm{AV \# 2})$ to the sites with seawater chemical anomalies.

In addition, 22 surficial sediments and 6 sediment box-cores over the study area (Fig. 1B) also were studied for evaluating the significance of diagenetic and/or benthic $\mathrm{Mn}$ contributions from the sediment column to the deeper settling particles of the SOT and for examining the influences of hydrothermal plumes on the sediment composition.

\subsection{Analyses}

In our work, all the pretreatments for diverse samples (i.e. trap samples, seawater and sediments) studied were carefully conducted in a class 100 laminar flow bench, and all containers used were acid-cleaned prior to use. Three GR (Guaranteed Reagents) acids of $\mathrm{HNO}_{3}, \mathrm{HF}$ and $\mathrm{HClO}_{4}$ (all from Merck) were used for total digestion of trap and sediment samples and Suprapur grade for all seawa- ter samples and sequential extraction of trap samples; the metal contents were low enough to satisfy the study. First, aliquots (1/5 for traps T5 and $1 / 7$ for T6) of trap samples $(\sim 1-10 \mathrm{~g})$ were rinsed twice with $100 \mathrm{ml}$ of distilled deionized water (DDW, $\mathrm{pH}$ 6.8), the particles were allowed to settle and the solution decanted to remove residual seawater and preservative. They were then dried at room temperature and ground to 100-200 mesh-sized powder using an agate mortar and pestle. Two 0.25 -g aliquots of each sample powder were subject to total digestion and SSSE to determine the total contents and phase associations of selected metals, respectively. The procedures and conditions for total digestion and for the last (sixth) stage of sequential extraction (lattice-held fraction) have been described (Hsu et al., 1998, 2003a). The optimized operational conditions (temperature and reaction times) and procedures used for SSSE are illustrated in Fig. 2. The extracts were separated from solids by centrifugation at $\sim 15000 \times g$ for $15 \mathrm{~min}$. All reagents (except three acids: $\mathrm{HNO}_{3}, \mathrm{HF}$ and $\mathrm{HClO}_{4}$ ) used in the SSSE were purified through Chelex-100 resin columns prior to use and then adjusted to required $\mathrm{pH}$ values.

After drying and weighing, particulate-laden filters were processed by the total digestion method using an acid mixture of Suprapur HF, $\mathrm{HNO}_{3}$ and $\mathrm{HClO}_{4}$. The filtrates for measurements of dissolved metals were pre-concentrated using Chelex-100 resin (100-200 mesh and ammonium form) columns after adjusting the $\mathrm{pH}$ to 6.5. The elution used $2 \mathrm{~N} \mathrm{HNO}_{3}$ (Merck Suprapur). Resin columns were pre-cleaned with $2 \mathrm{~N}$ Suprapur $\mathrm{HNO}_{3}$ and DDW twice before use. The conditions of preconcentration mainly followed those of Lin et al. (2000) and Hsu et al. (2003a). One liter of purified seawater (passed through Chelex-100 column two times) was spiked with known amounts of Mn and $\mathrm{Pb}(\mathrm{Mn}$ and $\mathrm{Pb}$ stock standard from Merck) and then subjected to preconcentration; one of these spiking experiments was repeated five times. The recovery and precision of $\mathrm{Mn}$ and $\mathrm{Pb}$ under preconcentration treatments were determined to be $90 \%$ and $4 \%$ for $\mathrm{Mn}$ and $77 \%$ and $4 \%$ for $\mathrm{Pb}(n=5)$.

Sediment cores were sectioned according to visual properties, e.g. color, grain size and texture. Thin scrapings of the surface layer of about $0.5 \mathrm{~cm}$ from box cores were regarded as surficial sediment. Sub- 
Table 1

Analysis of standard reference material, BCSS-1

\begin{tabular}{lccc}
\hline & Certified value & $\begin{array}{c}\text { This work (total } \\
\text { digestion, } n=5)\end{array}$ & $\begin{array}{l}\text { This work (sequential } \\
\text { extraction, } n=5)\end{array}$ \\
\hline $\mathrm{Al}$ & $6.263 \pm 0.217 \%$ & $6.239 \pm 0.089 \%$ & $5.691 \pm 0.078 \%$ \\
$\mathrm{Fe}$ & $3.287 \pm 0.098 \%$ & $3.266 \pm 0.056 \%$ & $3.047 \pm 0.044 \%$ \\
$\mathrm{Mn}$ & $229 \pm 15 \mathrm{mg} / \mathrm{kg}$ & $225 \pm 3 \mathrm{mg} / \mathrm{kg}$ & $210 \pm 1 \mathrm{mg} / \mathrm{kg}$ \\
$\mathrm{Pb}$ & $22.7 \pm 3.4 \mathrm{mg} / \mathrm{kg}$ & $19.2 \pm 0.3 \mathrm{mg} / \mathrm{kg}$ & $21.1 \pm 0.3 \mathrm{mg} / \mathrm{kg}$ \\
\hline
\end{tabular}

samples $(\sim 1-4 \mathrm{~g})$ were rinsed with $100 \mathrm{ml}$ DDW to remove residual saline water by the same procedures as trap samples, then dried and ground for total digestion as described above.

Metal determinations were made in triplicate using a Hitachi-Z8100 flame/flameless graphite furnace atomic absorption spectrophotometer (AAS) equipped with a Zeeman background correction system. Standards used for calibration were prepared in the same matrix (e.g. reagents used in each stage) as the samples. The optimized conditions for determining certain metals in extracted sample solutions by AAS followed those of Pai et al. (1993). Accuracy and precision were checked by replicate $(n=5)$ analysis of total metal concentrations in standard reference material BCSS-1 (National Research Council, Canada), following total digestion and SSSE. Accuracy and precision for $\mathrm{Al}, \mathrm{Fe}$ and $\mathrm{Mn}$ were within $10 \%$ of certified values and $\mathrm{Pb}$ within $15 \%$ (Table 1); also, total elemental content values by digestion and SSSE were in good agreement (Table 1). The percentage of each metal in the respective phase was normalized to the summed concentrations of the extracts. Elemental concentrations of each phase were calculated from the total contents of a metal multiplied by the phase percentage.

\section{Results and discussion}

The overall means and standard deviations for $\mathrm{Al}$, $\mathrm{Fe}, \mathrm{Mn}$ and $\mathrm{Pb}$ in the extraction phases for the sediment trap samples from T6 are given as percentages and concentrations in Tables 2 and 3, respectively. Time-series variations of phase associations of both $\mathrm{Mn}$ and $\mathrm{Pb}$ associated within individual samples from two depths are shown in Fig. 3. Results show that $\mathrm{Al}$ and $\mathrm{Fe}$ concentrations are rather uniform. Elemental fluxes that are estimated from the weight fraction of each element multiplied by the mass fluxes are listed in Table 4. The results reveal that the laterally transported terrigenous particles, likely driven by sediment discharge from Taiwan's rivers during flood periods, dominate in the components of settling particles and regulate the amounts of sediment mass fluxes in the SOT (Hsu et al., 2003b). In addition, for compositional comparison, the chemical data for three-depth trap samples from station T5, located at the outlet of Mien-hua Canyon to the SOT, northwestern to T6, are given in Table 5.

\subsection{Concentrations and phase associations for selected metals}

The total contents of $\mathrm{Al}$ and $\mathrm{Fe}$ in the $\mathrm{T} 6$ two-depth samples are almost equal (Table 3): $8.80 \pm 0.36 \%$ and $3.98 \pm 0.09 \%(n=12)$ for the shallower samples and $8.73 \pm 0.29 \%$ and $4.12 \pm 0.09 \%(n=12)$ for the

Table 2

Fractionation (\% of total) for $\mathrm{Al}, \mathrm{Fe}, \mathrm{Mn}$ and $\mathrm{Pb}$ within respective extraction phases for sediment trap samples from station $\mathrm{T} 6$ determined by six-stage sequential extraction

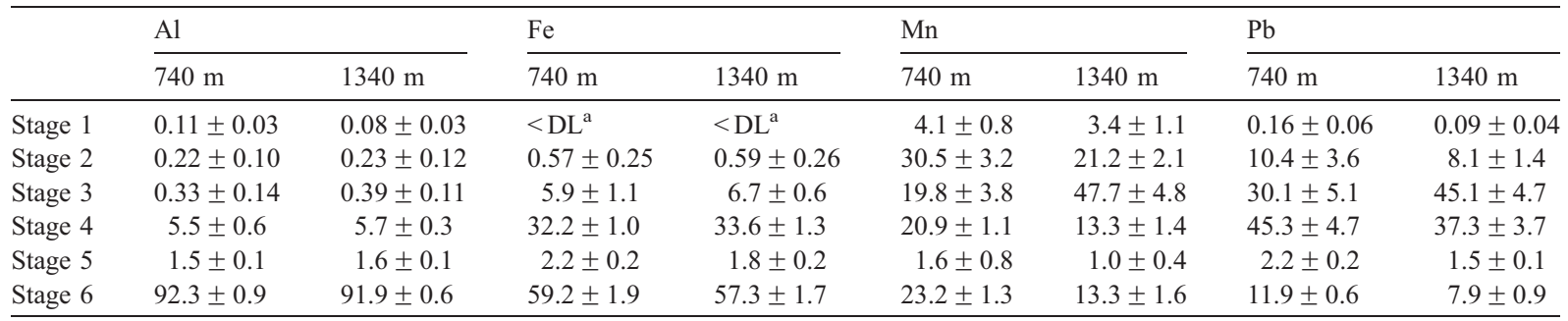

Means and one standard deviation are given for a composite of all 12 time-series samples for each trap.

${ }^{\mathrm{a}}$ Detection limit (DL) is $0.03 \%$. 
Table 3

Fractionation of $\mathrm{Al}, \mathrm{Fe}, \mathrm{Mn}$ and $\mathrm{Pb}$ for sediment trap samples from station $\mathrm{T} 6$ determined by six-stage sequential extraction

\begin{tabular}{|c|c|c|c|c|c|c|c|c|}
\hline & \multicolumn{2}{|l|}{$\mathrm{Al}(\%)$} & \multicolumn{2}{|l|}{$\mathrm{Fe}(\%)$} & \multicolumn{2}{|c|}{$\mathrm{Mn}(\mathrm{mg} / \mathrm{kg})$} & \multicolumn{2}{|l|}{$\mathrm{Pb}(\mathrm{mg} / \mathrm{kg})$} \\
\hline & $740 \mathrm{~m}$ & $1340 \mathrm{~m}$ & $740 \mathrm{~m}$ & $1340 \mathrm{~m}$ & $740 \mathrm{~m}$ & $1340 \mathrm{~m}$ & $740 \mathrm{~m}$ & $1340 \mathrm{~m}$ \\
\hline Stage 1 & $0.009 \pm 0.002$ & $0.007 \pm 0.002$ & $<\mathrm{DL}^{\mathrm{a}}$ & $<\mathrm{DL}^{\mathrm{a}}$ & $26 \pm 5$ & $38 \pm 11$ & $0.05 \pm 0.02$ & $0.04 \pm 0.02$ \\
\hline Stage 2 & $0.019 \pm 0.009$ & $0.020 \pm 0.010$ & $0.023 \pm 0.011$ & $0.024 \pm 0.010$ & $195 \pm 17$ & $236 \pm 23$ & $2.9 \pm 1.0$ & $3.6 \pm 1.1$ \\
\hline Stage 3 & $0.029 \pm 0.013$ & $0.034 \pm 0.009$ & $0.24 \pm 0.05$ & $0.28 \pm 0.03$ & $128 \pm 29$ & $539 \pm 106$ & $8.5 \pm 1.4$ & $19.7 \pm 3.5$ \\
\hline Stage 4 & $0.48 \pm 0.05$ & $0.50 \pm 0.03$ & $1.28 \pm 0.05$ & $1.38 \pm 0.06$ & $134 \pm 6$ & $148 \pm 7$ & $12.8 \pm 1.5$ & $16.3 \pm 2.4$ \\
\hline Stage 5 & $0.13 \pm 0.01$ & $0.14 \pm 0.01$ & $0.09 \pm 0.01$ & $0.07 \pm 0.01$ & $10 \pm 5$ & $12 \pm 4$ & $0.6 \pm 0.1$ & $0.6 \pm 0.1$ \\
\hline Stage 6 & $8.12 \pm 0.37$ & $8.03 \pm 0.30$ & $2.36 \pm 0.08$ & $2.36 \pm 0.09$ & $149 \pm 5$ & $148 \pm 5$ & $3.4 \pm 0.1$ & $3.4 \pm 0.1$ \\
\hline Total & $8.80 \pm 0.36$ & $8.73 \pm 0.29$ & $3.98 \pm 0.09$ & $4.12 \pm 0.09$ & $641 \pm 28$ & $1120 \pm 107$ & $28 \pm 1$ & $44 \pm 5$ \\
\hline
\end{tabular}

Means and one standard deviation are given for a composite of all 12 time-series samples for each trap.

${ }^{a}$ Detection limit (DL) is $0.001 \%$.

deeper samples. In contrast, $\mathrm{Mn}$ and $\mathrm{Pb}$ contents differ significantly between depths (Table 3): $641 \pm 28$ and $28 \pm 1 \mathrm{mg} / \mathrm{kg}$ for $\mathrm{Mn}$ and $\mathrm{Pb}$ in the shallower samples and $1120 \pm 107$ and $44 \pm 5 \mathrm{mg} / \mathrm{kg}$ in the deeper samples. Small standard deviations within the component data suggest temporal variations are insignif- icant (Table 3 and Fig. 3). Comparing the chemical data of T6 trap samples with those of T5 (Table 5) shows that $\mathrm{Fe}$ and $\mathrm{Mn}$ concentrations of the T6 shallower samples are similar to those of T5 samples but that for $\mathrm{Al}$ and $\mathrm{Pb}$ concentrations the $\mathrm{T} 6$ shallower samples are slightly higher than T5 samples. Mn and
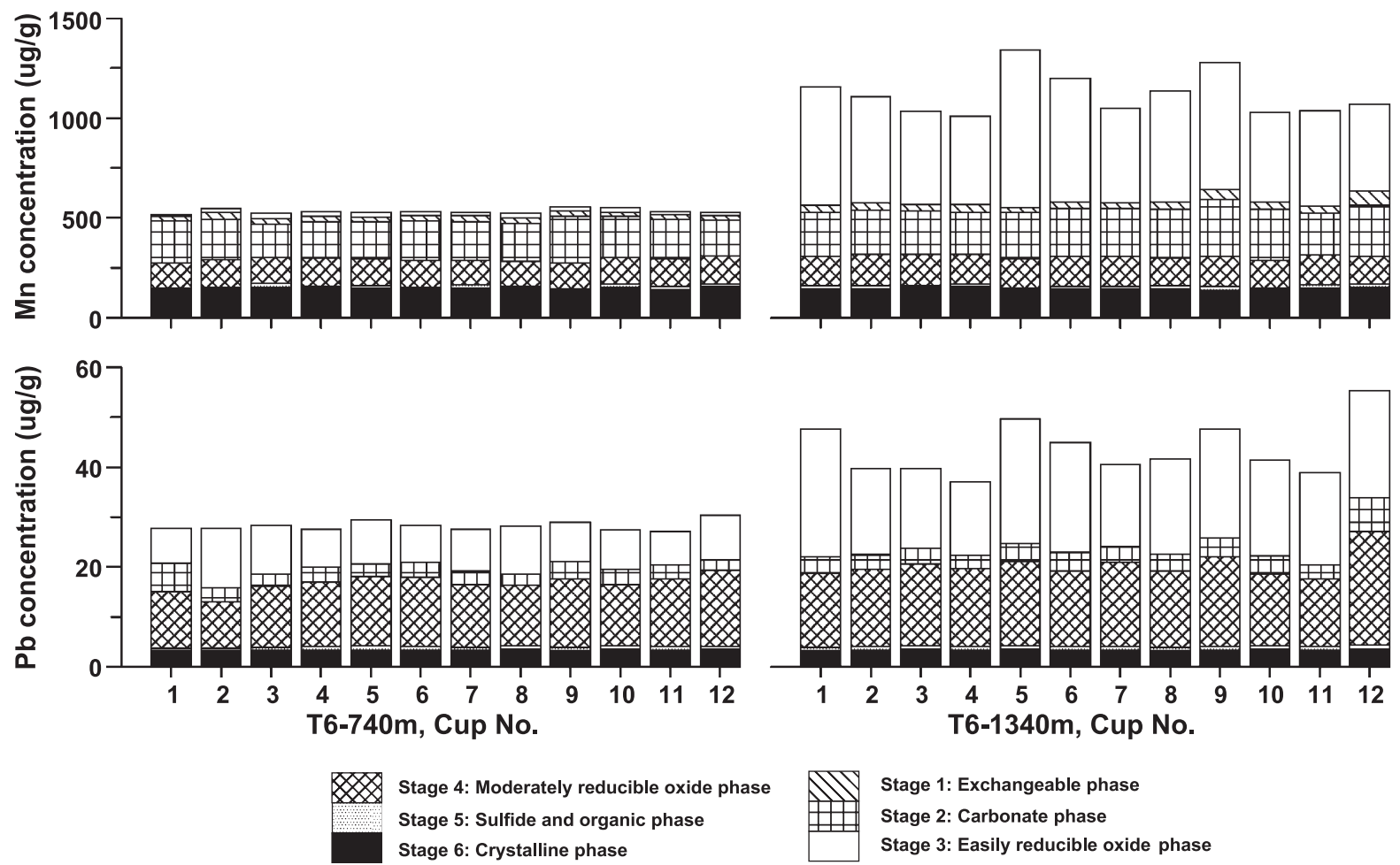

Stage 1: Exchangeable phase

Stage 2: Carbonate phase

Stage 3: Easily reducible oxide phase

Fig. 3. Time-series results for Mn (upper panels) and $\mathrm{Pb}$ (lower panels) within the phase associations (in units of $\mathrm{mg} / \mathrm{kg}$ ) for the sediment trap samples from T6. 
Table 4

Means ( \pm 1 S.D.) and ranges for sediment mass and elemental fluxes observed in sediment traps deployed at 740 and $1340 \mathrm{~m}$ at T6 in the SOT

\begin{tabular}{llllll}
\hline & $\begin{array}{l}\text { Mass flux } \\
\left(\mathrm{g} / \mathrm{m}^{2} / \text { day }\right)\end{array}$ & $\mathrm{Al}\left(\mathrm{g} / \mathrm{m}^{2} /\right.$ day $)$ & $\mathrm{Fe}\left(\mathrm{g} / \mathrm{m}^{2} /\right.$ day $)$ & $\mathrm{Mn}\left(\mathrm{mg} / \mathrm{m}^{2} /\right.$ day $)$ & $\mathrm{Pb}\left(\mathrm{mg} / \mathrm{m}^{2} / \mathrm{day}\right)$ \\
\hline $740 \mathrm{~m}$ & $3.05 \pm 1.00$ & $0.27 \pm 0.09$ & $0.12 \pm 0.04$ & $1.95 \pm 0.64$ & $0.09 \pm 0.03$ \\
& $(1.29-5.26)$ & $(0.10-0.47)$ & $(0.05-0.21)$ & $(0.81-3.46)$ & $(0.04-0.15)$ \\
$1340 \mathrm{~m}$ & $4.85 \pm 2.13$ & $0.42 \pm 0.19$ & $0.20 \pm 0.09$ & $5.32 \pm 2.18$ & $0.21 \pm 0.08$ \\
& $(2.15-7.46)$ & $(0.19-0.65)$ & $(0.09-0.31)$ & $(2.75-7.93)$ & $(0.10-0.33)$ \\
\hline
\end{tabular}

$\mathrm{Pb}$ enrichments in the 1340-m trap samples from $\mathrm{T} 6$, however, are still significant with respect to the 740-m trap samples from T6 or the samples from T5.

In terms of phase associations for the T6 sediment trap samples, most of the $\mathrm{Al}(92 \%)$ is partitioned within the residual (non-extractable) fraction (Table 2 ). These results are consistent with those for the adjacent sediments (e.g. stations 11 and 22 in Fig. 1) where $\mathrm{Al}$ is predominantly bound within the crystalline aluminosilicates $(>90 \%)$. Fe is mainly partitioned between the residual $(58 \pm 1 \%)$ and moderately reducible $(33 \pm 1 \%)$ fractions with small percentages in the easily reducible (about 6\%) and refractory organic (about 2\%) fractions. In contrast, $\mathrm{Mn}$ and $\mathrm{Pb}$ have largely different phase associations between the 740and $1340-\mathrm{m}$ samples. In the $740-\mathrm{m}$ samples, $\mathrm{Mn}$ is distributed among the carbonate $(30 \%)$, easily reducible $(20 \%)$, moderately reducible $(21 \%)$ and residual (23\%) fractions, while in the $1340-\mathrm{m}$ samples $\mathrm{Mn}$ in the easily reducible fraction (48\%) predominates over the other three fractions: carbonate (21\%), moderately reducible $(13 \%)$ and residual $(13 \%)$. In the $1340-\mathrm{m}$ samples, the pattern of phase associations of $\mathrm{Pb}$ is similar to that of Mn, with the easily reducible phase accounting for the largest proportions (45\%) and the moderately reducible phase the next largest fraction (37\%). However, in the 740-m samples, the Pb association follows a reverse order with the moderately reducible phase accounting for the highest fraction (45\%) compared to the easily reducible phase $(30 \%)$.

Large differences in phase associations for $\mathrm{Mn}$ and $\mathrm{Pb}$ were observed in the 730- and 1340-m trap samples from T6. However, for Fe, very small differences in abundance were observed in the various stages of the SSSE treatment (Table 3) in the 740- and 1340-m samples insignificant differences in concentration between the 740- and 1340-m trap samples for $\mathrm{Al}$ and $\mathrm{Fe}$ can be attributed to lithogenic particles (or aluminosilicate minerals) dominating (over 90\%) the composition of settling particles in the study area. Hydrothermal Fe and $\mathrm{Al}$ would be found in a less refractory phase and, therefore, the hydrothermally derived $\mathrm{Al}$ and $\mathrm{Fe}$ concentrations in all phases must be small compared to the background terrigenous particles. The small amount of hydrothermal $\mathrm{Fe}$ is consistent with the low $\mathrm{Fe}$ concentrations of hydrothermal fluids in the OT (e.g. $21 \mu \mathrm{M})$

Table 5

Results (mean \pm 1 S.D. and ranges) of elemental concentrations and M/Al ratios in trap samples from station T5, located upstream of T6 near the Mien-hua Canyon outlet

\begin{tabular}{|c|c|c|c|c|c|c|c|c|}
\hline Station & $\begin{array}{l}\text { Depth } \\
\text { (sample no.) }\end{array}$ & $\mathrm{Al}(\%)$ & $\mathrm{Fe}(\%)$ & $\begin{array}{l}\mathrm{Mn} \\
(\mathrm{mg} / \mathrm{kg})\end{array}$ & $\begin{array}{l}\mathrm{Pb} \\
(\mathrm{mg} / \mathrm{kg})\end{array}$ & $\mathrm{Fe} / \mathrm{Al}(\mathrm{g} / \mathrm{g})$ & $\begin{array}{l}\mathrm{Mn} / \mathrm{Al} \\
(\mathrm{mg} / \mathrm{g})\end{array}$ & $\mathrm{Pb} / \mathrm{Al}(\mathrm{mg} / \mathrm{g})$ \\
\hline \multirow[t]{3}{*}{$\mathrm{T} 5$} & $560 \mathrm{~m}(n=9)$ & $\begin{array}{l}7.7 \pm 0.7 \\
6.8-9.1\end{array}$ & $\begin{array}{l}3.8 \pm 0.3 \\
3.4-4.3\end{array}$ & $\begin{array}{l}608 \pm 37 \\
559-682\end{array}$ & $\begin{array}{l}20 \pm 2 \\
16-24\end{array}$ & $\begin{array}{l}0.49 \pm 0.03 \\
(0.44-0.55)\end{array}$ & $\begin{array}{l}7.9 \pm 0.5 \\
(7.3-8.8)\end{array}$ & $\begin{array}{l}0.26 \pm 0.03 \\
(0.22-0.30)\end{array}$ \\
\hline & $760 \mathrm{~m}(n=12)$ & $\begin{array}{l}7.9 \pm 0.6 \\
7.1-8.8\end{array}$ & $\begin{array}{l}3.9 \pm 0.2 \\
3.7-4.2\end{array}$ & $\begin{array}{l}654 \pm 38 \\
596-710\end{array}$ & $\begin{array}{l}20 \pm 2 \\
17-23\end{array}$ & $\begin{array}{l}0.50 \pm 0.02 \\
(0.47-0.54)\end{array}$ & $\begin{array}{l}8.3 \pm 0.4 \\
(7.6-8.9)\end{array}$ & $\begin{array}{l}0.25 \pm 0.02 \\
(0.23-0.31)\end{array}$ \\
\hline & $960 \mathrm{~m}(n=9)$ & $\begin{array}{l}7.8 \pm 0.5 \\
7.2-8.4\end{array}$ & $\begin{array}{l}4.0 \pm 0.2 \\
3.6-4.2\end{array}$ & $\begin{array}{l}738 \pm 93 \\
537-852\end{array}$ & $\begin{array}{l}20 \pm 2 \\
17-23\end{array}$ & $\begin{array}{l}0.51 \pm 0.02 \\
(0.47-0.54)\end{array}$ & $\begin{array}{l}9.5 \pm 1.2 \\
(6.5-11)\end{array}$ & $\begin{array}{l}0.26 \pm 0.02 \\
(0.23-0.29)\end{array}$ \\
\hline \multirow[t]{2}{*}{$\mathrm{T} 6$} & $740 \mathrm{~m}(n=12)$ & $\begin{array}{l}8.8 \pm 0.4 \\
7.9-9.1\end{array}$ & $\begin{array}{l}4.0 \pm 0.1 \\
3.9-4.1\end{array}$ & $\begin{array}{l}641 \pm 28 \\
571-673\end{array}$ & $\begin{array}{l}28 \pm 1 \\
27-30\end{array}$ & $\begin{array}{l}0.45 \pm 0.02 \\
(0.43-0.52)\end{array}$ & $\begin{array}{l}7.3 \pm 0.5 \\
(6.3-7.9)\end{array}$ & $\begin{array}{l}0.32 \pm 0.02 \\
(0.30-0.39)\end{array}$ \\
\hline & $1340 \mathrm{~m}(n=12)$ & $\begin{array}{l}8.7 \pm 0.3 \\
8.4-9.4\end{array}$ & $\begin{array}{l}4.1 \pm 0.1 \\
4.0-4.3\end{array}$ & $\begin{array}{l}1120 \pm 107 \\
1008-1341\end{array}$ & $\begin{array}{l}44 \pm 5 \\
37-55\end{array}$ & $\begin{array}{l}0.47 \pm 0.01 \\
(0.45-0.49)\end{array}$ & $\begin{array}{l}13 \pm 1.1 \\
(7.9-16)\end{array}$ & $\begin{array}{l}0.50 \pm 0.06 \\
(0.39-0.65)\end{array}$ \\
\hline
\end{tabular}

Data for the T6 trap samples are also listed for comparison. 
relative to those of other hydrothermal systems from the open ocean and most backarc basins (Ishibashi and Urabe, 1995). Moreover, high scavenging rates of hydrothermally dissolved $\mathrm{Fe}$ (Cowen et al., 1990) lead to limited dispersion for dissolved Fe of hydrothermal origin. As a result, the effect of hydrothermal plumes on the Fe content of suspended, settling and sedimentary particles around hydrothermal fields in the SOT is likely to be small. This reasoning is quite consistent with our observations about total suspended matter, trap samples and sediments. However, the estimated hydrothermally derived flux of Fe superimposed on settling particles at $1340 \mathrm{~m}$ in the SOT is still high relative to that of Mn even though it accounts for only a small fraction (4\%) of the total flux of Fe, which will be discussed later.

Metal/aluminum ratios in sediment trap samples and surface sediments were used to identify parent materials and/or sources because $\mathrm{Al}$ can be regarded as an indicator of lithogenic particles (Hsu et al., 1998). The $\mathrm{Mn} / \mathrm{Al}\left[\mathrm{g} / \mathrm{g},(7.3 \pm 0.5) \times 10^{-3}, n=12\right]$ and $\mathrm{Pb} / \mathrm{Al}\left[\mathrm{g} / \mathrm{g},(0.32 \pm 0.02) \times 10^{-3}, n=12\right]$ ratios as well as total elemental contents in the 740 -m samples from T6 (Table 5) are consistent with those of adjacent slope surficial sediments (Table 6). Coupled with the increasing fluxes of sediment mass with depth (Hsu et al., 2003b), this suggests that most of settling particles originated as laterally transported sediments that consist mostly of aluminosilicate detritus with temporally constant composition, as supported by $\mathrm{Al}$ concentrations of most surficial sediments (except for shelf sediments that are dominated by relict sediments) containing more than $8 \%$ of $\mathrm{Al}$ (Table 6). Meanwhile, the $\mathrm{Al}$ and Fe contents and the $\mathrm{Fe} / \mathrm{Al}$ ratio of the $1340-\mathrm{m}$ samples matches the sediments and shallower trap samples. This suggests that lithogenic particles dominate the flux through the water column and the accumulation in sediments and that hydrothermal enrichment of $\mathrm{Fe}$ is not significant. Moreover, almost identical residual (refractory) fractions for all analyzed elements (Al, Fe, Mn and $\mathrm{Pb}$ ) are found at both sample depths, revealing that settling particles at the two depths have the same original chemical natures (Landing and Bruland, 1987). Thus, detrital particles have become enriched in $\mathrm{Mn}$ and $\mathrm{Pb}$ in the 1340-m trap samples when they settled through a hydrothermal plume $(\sim 1300 \mathrm{~m})$.

\section{2. $\mathrm{Mn}$ and $\mathrm{Pb}$ anomalies in deeper water samples affected by hydrothermal activities}

The recent multidisciplinary surveys mentioned above confirm that hydrothermal activity exists regionally in the SOT (Lee et al., 1998, 2000; Chan et al., 2000) (Fig. 1). Furthermore, water column anomalies for seawater Mn (e.g. dissolved Mn 23.5 $\mathrm{nM}$ at $1300 \mathrm{~m}$ of station c) (Fig. 4) and $\mathrm{Pb}$ (e.g. slight enrichment for particulate $\mathrm{Pb}$ at $1300 \mathrm{~m}$ of station $\mathrm{c}$ ) (Fig. 5) and dissolved $\mathrm{CH}_{4}$ (e.g. $550 \mathrm{nM}$ in bottom water of station DP) (Fig. 6) have been observed at depths between 1200 and 1400 m near the collection site of the T6 trap samples. An active hydrothermal analogue (e.g. chimney or seamount) seen in Fig. 1 is quite near station DP with a $\mathrm{CH}_{4}$ anomaly in the nearbottom water. The high $\mathrm{CH}_{4}$ and low $\mathrm{Mn}$ concentrations observed in this sediment-rich hydrothermal system are similar to those measured in the Guaymas basin, Gulf of California (Welhan, 1988; Cruse and Seewald, 2001). These two sites are located in sediment-covered environments and sediments can substantially affect the chemical compositions and characteristics of hydrothermal venting. For instance, $\mathrm{CH}_{4}$ can be generated via thermocatalysis of organic matter (thermogenesis) when the high-temperature and low-pH hydrothermal solution interacts with sediments (Welhan, 1988).

Table 6

Elemental concentrations and $\mathrm{M} / \mathrm{Al}$ ratios (mean \pm 1 S.D. and range) of surficial sediments

\begin{tabular}{clllllll}
\hline & $\mathrm{Al}(\%)$ & $\mathrm{Fe}(\%)$ & $\mathrm{Mn}(\mathrm{mg} / \mathrm{kg})$ & $\mathrm{Pb}(\mathrm{mg} / \mathrm{g})$ & $\mathrm{Fe} / \mathrm{Al}(\mathrm{g} / \mathrm{g})$ & $\mathrm{Mn} / \mathrm{Al}(\mathrm{mg} / \mathrm{g})$ & $\mathrm{Pb} / \mathrm{Al}(\mathrm{mg} / \mathrm{g})$ \\
\hline All samples & $8.2 \pm 1.3$ & $4.4 \pm 0.7$ & $1722 \pm 1369$ & $35 \pm 17$ & $0.54 \pm 0.03$ & $20 \pm 15$ & $0.42 \pm 0.16$ \\
$\quad(n=21)^{\mathrm{a}}$ & $(4.5-9.6)$ & $(2.8-5.2)$ & $(446-4647)$ & $(14-69)$ & $(0.47-0.73)$ & $(6-54)$ & $(0.21-0.75)$ \\
Slope samples & $7.3 \pm 1.9$ & $3.9 \pm 0.8$ & $718 \pm 282^{\mathrm{b}}$ & $22 \pm 6$ & $0.52 \pm 0.05$ & $13 \pm 8$ & $0.28 \pm 0.05$ \\
$(n=9)$ & $(4.5-9.6)$ & $(2.8-5.0)$ & $(446-1247)$ & $(14-32)$ & $(0.47-0.61)$ & $(6-31)$ & $(0.21-0.39)$ \\
\hline
\end{tabular}

\footnotetext{
${ }^{\text {a }}$ Station 1 excluded because it contained heavy minerals.

${ }^{\mathrm{b}} \mathrm{Mn}$ data for station 7 was omitted for calculating mean because it is in the oxidized zone.
} 
(a)

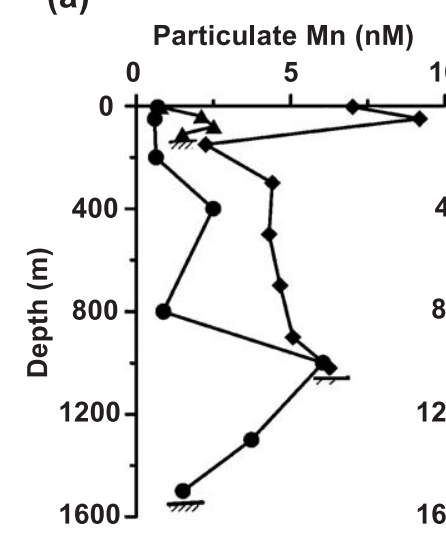

(b)

(c) Dissolved Mn (nM) Particulate $\mathrm{Mn} / \mathrm{Al}$ ratio $(\mathrm{mg} / \mathrm{g})$

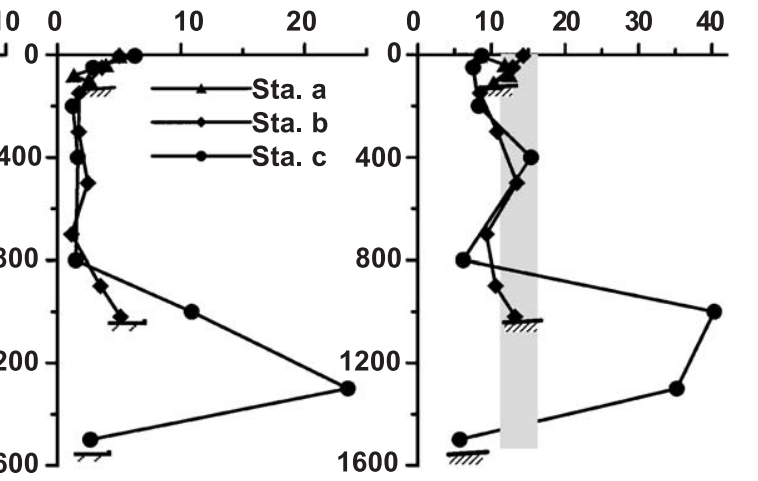

Fig. 4. Profiles of Mn (dissolved and particulate phases) from three stations crossing shelf-slope-trough in the study area: (a) particulate Mn concentrations, (b) dissolved $\mathrm{Mn}$ concentrations and (c) particulate $\mathrm{Mn} / \mathrm{Al}$ ratios. The shaded area indicates the $\mathrm{Mn} / \mathrm{Al}$ ratio of average crustal composition (Taylor, 1964; Taylor and McLennan, 1985).

The circulation pattern in the SOT is important for the dispersion of hydrothermal emanations. The Kuroshio Current, flowing northward along the east coast of Taiwan, is the main current influencing the circulation pattern in shallow water (above $600 \mathrm{~m}$ ) of the study area. When approaching the sea off northeast Taiwan, it collides with the shoaling east-west shelf of the southern East China Sea. The Kuroshio Current main stream thus turns northeastward almost along the shelf break. In the SOT the Kuroshio Current occupies the top $600 \mathrm{~m}$; in other words, the flow direction is dominantly north. However, the prevailing directions of deep flows indicated by the recorded data of current meters attached to the T6 sediment trap mooring array were south at $900 \mathrm{~m}$ and southeast at $1200 \mathrm{~m}$; the mean flow speeds were 5 and $3 \mathrm{~cm} / \mathrm{s}$, respectively (Chung and Hung, 2000). Occasionally, eastern and southeastern directions were recorded at $900 \mathrm{~m}$, while at $1200 \mathrm{~m}$ the flow direction and speed were reasonably steady. The deep current with a prevailing SE direction (Chung and Hung, 2000) will presumably disperse the venting solution, becoming a hydrothermal plume. Thus, hydrothermal plumes enriched in $\mathrm{Mn}$ and possibly other trace metals may advect (a)

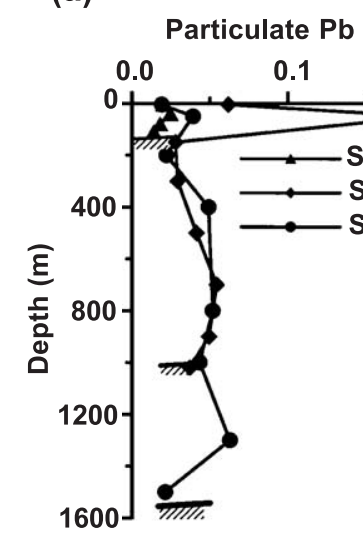

(b) (c)

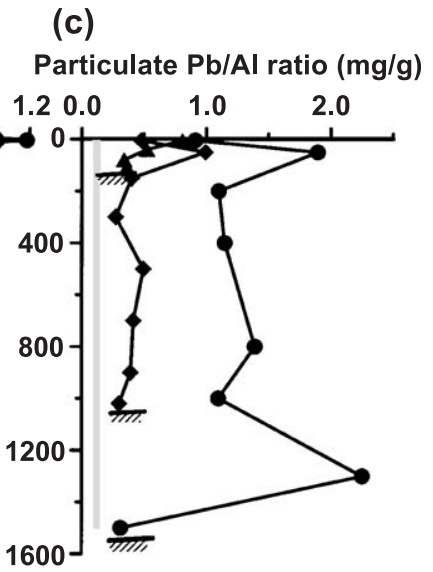

Fig. 5. Profiles of $\mathrm{Pb}$ (dissolved and particulate phases) from three stations crossing shelf-slope-trough in the study area: (a) particulate $\mathrm{Pb}$ concentrations, (b) dissolved $\mathrm{Pb}$ concentrations and (c) particulate $\mathrm{Pb} / \mathrm{Al}$ ratios. The shaded area indicates the $\mathrm{Pb} / \mathrm{Al}$ ratio of average crustal composition (Taylor, 1964; Taylor and McLennan, 1985). 


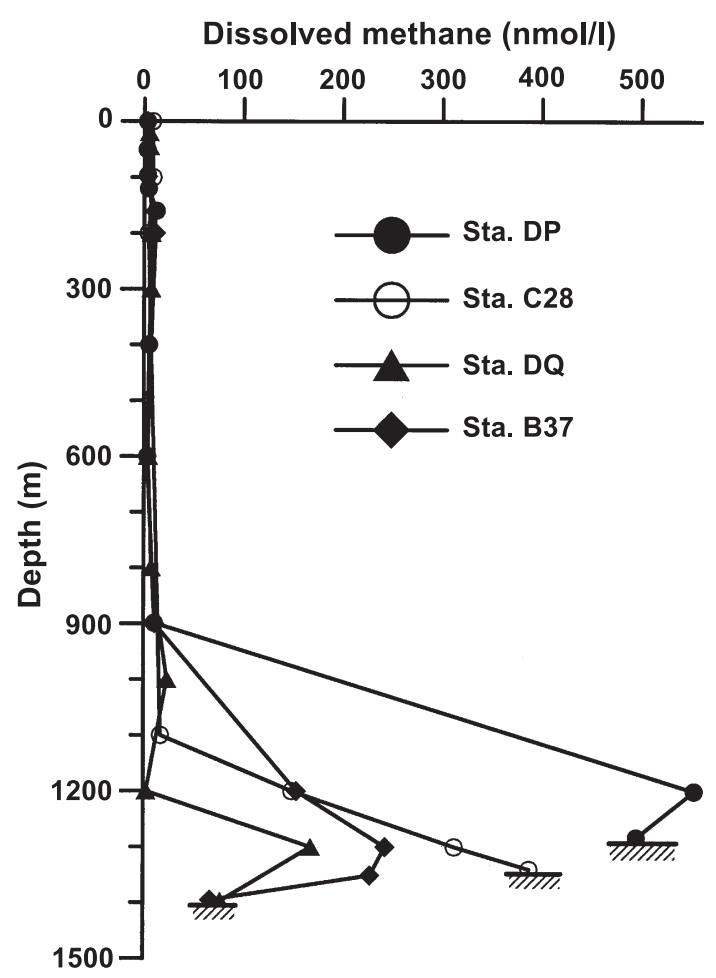

Fig. 6. Dissolved $\mathrm{CH}_{4}$ in the water column near a submarine volcanic analogue that has been persistently emanating hydrothermal fluids (from Chen, 1994).

horizontally near the $\sim 1300-\mathrm{m}$ isopycnal in this region. Settling particles that interact with this plume may become enriched in hydrothermally derived trace elements (Sherrell et al., 1999) as suggested by our observations of increased $\mathrm{Mn}$ and $\mathrm{Pb}$ contents in the 1340-m samples from $\mathrm{T} 6$.

The high degree of correlation between total Mn and $\mathrm{Pb}$ contents in the deeper samples (Fig. 7a) suggests three possible causes for these enrichments: (1) direct contributions of the two elements simultaneously from the same source; (2) enrichment due to the similar process (e.g. scavenging of $\mathrm{Mn}$ from ambient water by hydrothermal precipitates) occurring at depth, likely relevant to hydrothermal activity; and/ or (3) enrichment of one element directly from hydrothermal sources and the other by processes related to hydrothermal activity. The higher correlation between total $\mathrm{Pb}$ contents for the 740- and 1340-m trap samples (Fig. 7b) compared to Mn (Fig. 7c) suggests that the sources or processes resulting in the increased
$\mathrm{Pb}$ contents of the 1340-m samples are different from those for Mn. Additionally, the hydrothermally derived $\mathrm{Mn}$ and $\mathrm{Pb}$ concentrations in the 1340-m trap samples (defined as "excess", described later) have also a better correlation (Fig. 7d). While no literature data are available for $\mathrm{Pb}$ concentrations in the hydrothermal solutions of the OT, a number of researchers (Halbach et al., 1989; Aoki and Nakamura, 1989) found the massive sulfides here to be enriched in $\mathrm{Pb}$. Our dissolved $\mathrm{Pb}$ data in the water column (Fig. 5) from station c with anomalous seawater Mn (Fig. 4) show a slight increase in concentration at the depth of $1300 \mathrm{~m}$ relative to its neighboring depths. Because $\mathrm{Pb}$ is a particle-reactive element $(\mathrm{Li}, 1981)$, it may be easily removed from the water column via coprecipitation or adsorption onto fine oxide surfaces of settling particles. Amorphous $\mathrm{Mn}$ oxide (and Fe hydroxide) precipitates of hydrothermal origin may thus become effective scavengers of seawater $\mathrm{Pb}$ regardless of its origin. Such reasoning is consistent with the (slightly) higher particulate $\mathrm{Pb}$ concentration (Fig. 5a) and maximum $\mathrm{Pb} / \mathrm{Al}$ ratio (Fig. 5c) at the same depth $(1300 \mathrm{~m})$ as dissolved $\mathrm{Pb}$ (Fig. 5b). Deficiencies of ${ }^{210} \mathrm{~Pb}$ in OT deep water, observed by Nozaki et al. (1990), also resulted from this mechanism of scavenging. Whether the $\mathrm{Pb}$ anomalies in the deeper samples discussed here are supplied by scavenging or directly from hydrothermal sources cannot be readily assessed.

\subsection{Evaluating the significance of diagenetic/benthic sources to the Mn enrichments of the SOT deeper settling particles}

As is well known, remobilized Mn via sedimentary diagenesis can be an important Mn source in the particulate and/or dissolved phases, particularly in marginal seas. Resuspension of surficial sediments and mixing of dissolved $\mathrm{Mn}$ out of the sediments may yield locally elevated dissolved and particulate Mn concentrations (Landing and Bruland, 1987), as observed in the bottom water of station b (Fig. 4a and b), i.e. upstream of station c. While on the shelf, for example, at station a, the near-bottom concentration of dissolved $\mathrm{Mn}$ is much smaller, compared to the maximum observed at $1300 \mathrm{~m}$ at station c (Fig. 4a). Additionally, the similar particulate $\mathrm{Mn} / \mathrm{Al}$ ratios in surficial sediments and lithogenic materials (Fig. 4c) 

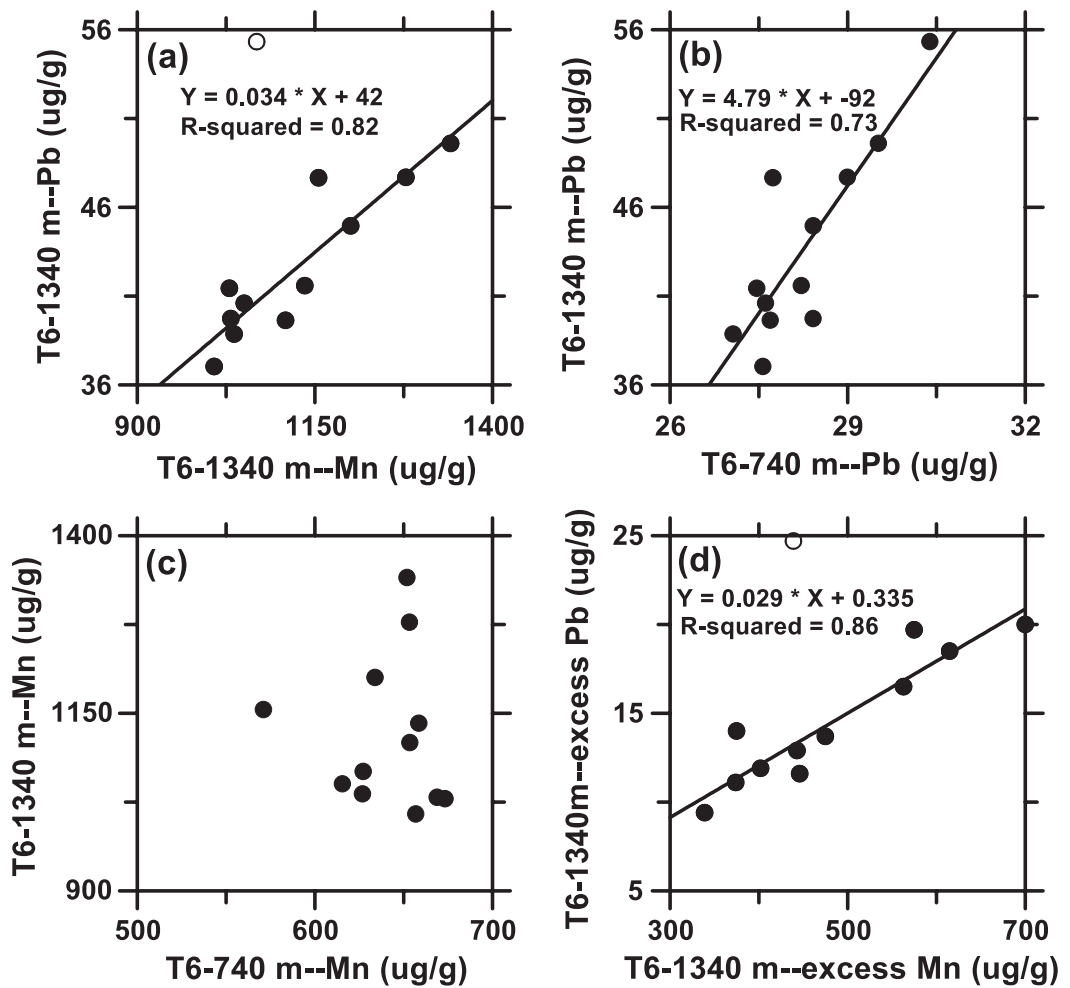

Fig. 7. Relationships between (a) total $\mathrm{Mn}$ and total $\mathrm{Pb}$ concentrations in the 1340-m trap samples from $\mathrm{T} 6$; (b) total $\mathrm{Pb}$ concentrations in the 740- and 1340-m trap samples; (c) total Mn concentrations in the 740- and 1340-m trap samples; and (d) excess $\mathrm{Mn}$ and excess $\mathrm{Pb}$ concentrations in the 1340-m trap samples. Regression coefficients are given in plots (a), (b) and (d), but not in plot (c) because there is no correlation. In plots (a) and (d), an outlier shown in open circles was excluded from the regression. The calculation of excess $\mathrm{Mn}$ and $\mathrm{Pb}$ in the $1340-\mathrm{m}$ samples is described in the text.

indicate little enrichment of $\mathrm{Mn}$ in suspended materials upstream of the hydrothermal plume (Fig. 4). The decreasing trend in the concentrations of dissolved Mn from shelf and slope to trough and a low concentration of dissolved Mn measured in the bottom water of station $\mathrm{c}$ allow us to infer that there are no significant contributions of Mn from diagenetic and/ or benthic sources to the deeper settling particles in the study area. In other words, the Mn enrichments in deeper settling particles were caused predominately by the hydrothermal plume ascending from a site very close to station AV\#2 (a submarine volcano with a $\mathrm{CH}_{4}$ anomaly; Chen, 1994).

Hydrothermal emanations can extensively affect the composition of ambient seawater and sediments both adjacent to and hundreds of kilometers downstream of hydrothermal fields. Based on the present available chemical data for sediment in the study area, enrichments of $\mathrm{Mn}$ and $\mathrm{Pb}$ can be seen in the surface oxidized zone of trough sediments but not of slope sediments (Mn shown in Table 6 and Fig. 8). The abundance of $\mathrm{Mn}$ in surface sediments over the study area increases offshore with depth, and the Mn-oxide surface layer can be easily identified in sediments at the trough station (e.g. station 18), indicating strong diagenesis in the deep trough (although no pore water data are available to verify this). Nevertheless, the impact from hydrothermal emanations yields $\mathrm{Mn}$ and $\mathrm{Pb}$ enrichments at station 16 (near station $\mathrm{T} 6$ ) that are similar to the 1340-m trap samples from T6. Also, the Mn concentrations decrease sharply with depth in the sediment column, revealing a thin $(<2 \mathrm{~cm})$ oxidized layer. This is different from the other two trough sediment cores such as stations 18 and 21 with thicker (at least $>3 \mathrm{~cm}$ ) oxidized zones (Fig. 8). The Mn sedimentary profile at station 16 likely implies that the 


\section{$\mathrm{Mn}$ ( $\mathrm{mg} / \mathrm{kg})$}

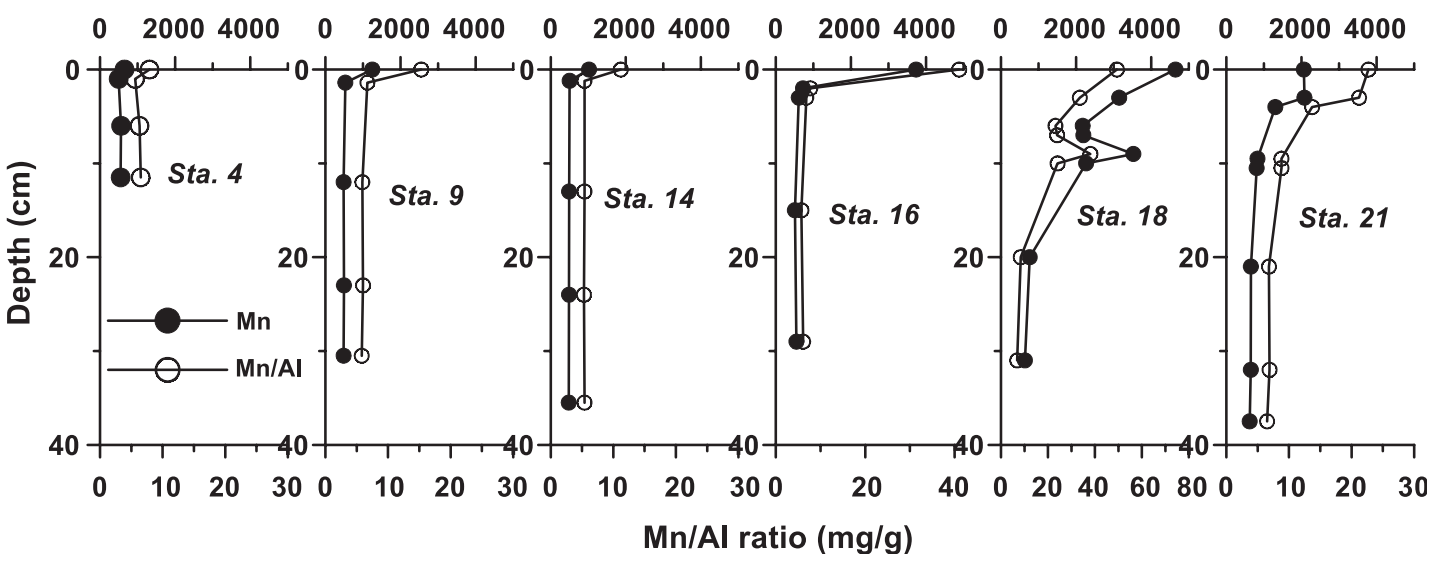

Fig. 8. Depth profiles of total Mn concentrations and $\mathrm{Mn} / \mathrm{Al}$ ratios for six box-cores.

Mn surface enrichments not only resulted from diagenetic contributions but also from hydrothermal contributions. However, the $\mathrm{Mn}$ and $\mathrm{Pb}$ enrichments are relatively small, compared to the massive sulfides found in the vicinity of hydrothermal systems in the middle OT (Halbach et al., 1989; Urabe, 1989; Aoki and Nakamura, 1989). Hydrothermally derived precipitates (e.g. massive sulfides) have not been found in trough sediments in the study area at present, and it is thus presumed that they must be locally confined in the vicinity of hydrothermal chimneys (or their analogue). Moreover, hydrothermal signatures superimposed on trough sediments may be more difficult to identify partly because the high sedimentation rates (over $0.1 \mathrm{~cm} /$ year) of terrigenous material overshadows the hydrothermal input.

On the other hand, the large amounts of terrigenous sediment deposited on the seafloor can be expected to exert great influence on the chemical composition of the hydrothermal solutions as they interact with high temperature/low $\mathrm{pH}$ of hydrothermal fluids (Welhan, 1988; Cruse and Seewald, 2001). For example, hydrothermal venting observed in the middle OT had slightly high $\mathrm{pH}(\sim 5.0)$ as well as high $\mathrm{CO}_{2}$ and $\mathrm{CH}_{4}$, compared to those observed in the East Pacific Rise and the Middle Atlantic Ridge (Ishibashi and Urabe, 1995). Hydrothermal $\mathrm{CH}_{4}$ of up to $550 \mathrm{nM}$ measured in the study area by Chen (1994) was much larger than typical values (generally less than $50 \mathrm{nM}$ ) from other hydrothermal fields (Charlou et al., 1991;
Charlou and Donval, 1993; Ishibashi et al., 1997) including the middle OT (400 nM; Halbach et al., 1989). Welhan (1988) suggested that the anomalous $\mathrm{CH}_{4}$ observed in the Guaymas Basin is produced through thermocatalysis of organic matter in sediments, and the dramatic decay of $\mathrm{CH}_{4}$ concentrations in hydrothermal plumes with dispersed distances is primarily regulated by the microbial oxidation process along with dilution of the plume with background waters (Cowen et al., 2002).

\subsection{The use of sequential extraction to partition hydrothermally derived particulate metals}

Even though both $\mathrm{Mn}$ and $\mathrm{Pb}$ are particle-reactive elements, significant differences in chemical behavior and origin can be identified using their phase associations. Comparing the partitioning of $\mathrm{Mn}$ and $\mathrm{Pb}$ in the 740- and 1340-m trap samples at T6 shows that all phase associations except the new oxide have very similar concentrations (Table 2 and Fig. 3). The almost constant concentrations in the crystalline fraction for all studied elements in the 740- and 1340-m trap samples reveals that the refractory, non-reactive phases are common at both depths. Furthermore, differences in the total content of $\mathrm{Mn}$ and $\mathrm{Pb}$ between the 740- and 1340-m samples are contributed primarily by the "easily reducible" (stage 3$)$ phase $(85 \pm 6 \%$ for $\mathrm{Mn}$ and $71 \pm 17 \%$ for $\mathrm{Pb}$ ). From the operational definition of the SSSE, results of phase associations 
suggest that the "excesses" of both $\mathrm{Mn}$ and $\mathrm{Pb}$ in the settling particles at $1340 \mathrm{~m}$ are present as fresh accretions or coatings of meta-stable oxides on particle surfaces via adsorption and/or oxidative conversion from dissolved forms to particulate forms (Landing and Bruland, 1987). In other words, the higher $\mathrm{Mn}$ and $\mathrm{Pb}$ concentrations in the 1340-m trap samples were enhanced after the settling particles reached the deeper hydrothermally enriched water $(\sim 1300 \mathrm{~m})$ and interacted with the hydrothermal plume. This study demonstrates that the SSSE can be capable of discriminating hydrothermal chemical signatures superimposed on settling particles.

\subsection{Equilibrium between the hydrothermally derived dissolved Mn and settling particulates in deep water and estimations of hydrothermally derived Mn fluxes scavenged by deeper settling particles}

Sediment mass and elemental (Al, Fe, $\mathrm{Mn}$ and $\mathrm{Pb}$ ) fluxes (Table 4) observed from the deeper trap ranged by a factor of $\sim 4$ and covaried temporally (all the correlation coefficients between any two parameters $>0.98$ ), whereas the variations in Mn concentrations for the deeper trap samples were quite small (1008$1341 \mu \mathrm{g} / \mathrm{g}$ ). The hydrothermally derived Mn fluxes scavenged by settling particulates in deep water can be obtained by multiplying excess Mn concentrations in deeper samples, defined as the increase in $\mathrm{Mn}$ concentrations of reactive associations (i.e. from stage 1 to stage 4) in deeper samples relative to shallower samples (i.e. $\Delta C$ in Table 7), by the sediment mass fluxes. They fell in a range of $1.2-4.6 \mathrm{mg} / \mathrm{m}^{2} /$ day (or $8-30 \mathrm{mM} / \mathrm{m}^{2} /$ year) (Table 7 ); this estimate is much

Table 7

Estimated hydrothermally derived fluxes $\left(\mathrm{mg} / \mathrm{m}^{2} /\right.$ day) for $\mathrm{Fe}, \mathrm{Mn}$ and $\mathrm{Pb}$ in the $1340-\mathrm{m}$ sediment trap samples at T6 in the SOT

\begin{tabular}{llll}
\hline & $\mathrm{Fe}$ & $\mathrm{Mn}$ & $\mathrm{Pb}$ \\
\hline$\Delta C_{\text {excess }}$ & $0.145 \%$ & $478 \mathrm{mg} / \mathrm{kg}$ & $15.3 \mathrm{mg} / \mathrm{kg}$ \\
$\begin{array}{c}F_{\text {hydrothermal }}\left(\mathrm{mg} / \mathrm{m}^{2} / \text { day }\right) \\
f(\%)\end{array}$ & $7.04 \pm 3.09$ & $2.32 \pm 1.02$ & $0.074 \pm 0.033$ \\
$f(4)$ & 44 & 36 \\
\hline
\end{tabular}

The $\Delta C_{\text {excess }}$ for each element represents the sum of extraction stages 1 through 4 for the 1340-m trap samples minus the same sum for the 740-m trap samples. Multiplying $\Delta C_{\text {excess }}$ by the total mass flux at $1340 \mathrm{~m}$ yields an estimate of the hydrothermally derived flux. Fractions $(f)$ represent the hydrothermally derived flux divided by the total flux for each element. higher than that $\left(1.7-3.4 \mathrm{mM} / \mathrm{m}^{2} /\right.$ year $)$ measured in the non-buoyant plume of the Juan de Fuca Ridge by Cowen et al. (1990). From these relatively constant scavenged fluxes, abundance and partitioning patterns of $\mathrm{Mn}$ in the deeper trap samples, a phase equilibrium is implied between hydrothermally derived dissolved $\mathrm{Mn}$ and settling particles.

Such high hydrothermally derived particulate Mn fluxes demonstrate that settling macroaggregates promote the removal of fine $\mathrm{Mn}$ (or other constituents such as $\mathrm{Fe}$ and $\mathrm{Pb}$ )-enriched particulates (e.g. Bertram et al., 2002) which may be scavenged from hydrothermal plumes by capsuled bacteria, as suggested by Lavelle et al. (1992). In this marginal sea, with especially high levels of suspended $(>0.1 \mathrm{mg} / \mathrm{l}$ below $500 \mathrm{~m}$ depth) and settling particles (settling sediment fluxes averaging $19 \mathrm{~g} / \mathrm{m}^{2} /$ day and ranging $4-46 \mathrm{~g} / \mathrm{m}^{2} /$ day) (Hsu et al., 1998, 2003b) relative to other oceans, the hydrothermal $\mathrm{Mn}$ and/or Fe can be effectively removed. However, at the same time, abundant supplies of terrigenous particles and thus rapid sedimentation rates would reduce the hydrothermal signature superimposed on settling and sedimentary particles, especially for the major crustal elements such as Fe. In other words, incorporation of hydrothermally enriched-Fe precipitates into settling and sedimentary particles might insignificantly change the $\mathrm{Fe}$ abundances even though the estimated hydrothermally derived Fe fluxes of the T6 deeper trap samples are as high as two times the Mn fluxes. Nevertheless, in the vicinity of hydrothermal vents, the hydrothermally derived constituents can substantially modify particulate compositions and concentrations of trace elements such as $\mathrm{Mn}$ and $\mathrm{Pb}$, as observed in this study. The hydrothermally derived $\mathrm{Fe}$ and $\mathrm{Pb}$ fluxes are also estimated, $7.0 \pm 3.1$ and $0.07 \pm 0.03 \mathrm{mg} / \mathrm{m}^{2} /$ day, respectively (Table 7). These estimated fluxes accounted for only $4 \%$ of the total Fe fluxes, $44 \%$ of the total Mn fluxes and $36 \%$ of the total $\mathrm{Pb}$ fluxes observed at $1340 \mathrm{~m}$ in the SOT.

The SOT is in a unique but complicated environment; for instance, its seafloor is developing on the continental crust, is overlain by a thick layer (1-3 $\mathrm{km}$ ) of sediments, has high sedimentation rates and its overlying water has high suspended loads. The composition of hydrothermal solutions can be modified through interactions with the overlying sediments, and the dispersion of hydrothermal constituents (e.g. 
dissolved $\mathrm{Fe}$ and $\mathrm{Mn}$ ) in hydrothermal plumes can be regulated by removal processes that are enhanced by high levels of suspended particles. The conversion of dissolved $\mathrm{Mn}$ of hydrothermal origin to particulate $\mathrm{Mn}$ incorporated into settling particles has been quantified. The impact of hydrothermal Mn on deposited sediments, however, could only be qualitatively evaluated due to our limited data set of sediment composition.

\section{Acknowledgements}

We are grateful to two reviewers, Profs. J.A. Resing (The Joint Institute for the Study of the Atmosphere and the Ocean, NOAA) and W.M. Landing (Department of Oceanography, Florida State University), and one anonymous reviewer for their constructive comments. We thank the technicians and crew of $\mathrm{R} / \mathrm{V}$ Ocean Researcher $I$ for help with sampling. Thanks are also extended to Dr. K.W. Hung and Mr. K. Huang for pretreatment of samples. We are grateful for the helpful comments from Dr. S.J. Kao. Fig. 1B was provided by the National Center for Ocean Research, Taiwan. This research was financed by the National Science Council, ROC. SCH was supported through NSC grants (NSC 84-2611M002A-007K2 and NSC 85-2611-M002A-026K2) to FJL.

$$
\text { Associate editor: Dr. William M. Landing. }
$$

\section{References}

Aoki, M., Nakamura, K., 1989. The occurrences of chimneys in Izena Hole No. 2 ore body and texture and mineral composition of the sulfide chimneys. Proc. JAMSTEC Symp. Deep Sea Res., vol. 5, pp. 197-210. In Japanese with English abstract.

Aplin, A.C., Cronan, D.S., 1985. Ferromanganese oxides deposits from the central Pacific Ocean, II. Nodules and associated sediments. Geochim. Cosmochim. Acta 49, 437-451.

Bernhard, M., Brinckman, F.E., Sadler, P.J., 1986. The Importance of Chemical "Speciation" in Environmental Processes. SpringerVerlag, Berlin. 762 pp.

Bertram, M.A., Cowen, J.P., Thomson, R.E., Feely, R.A., 2002. Compositional variability in the ascending fluxes from a hydrothermal plume. J. Geophys. Res. 107 (C11), 3191 (doi:10.1029/ 2000JC000223).

Bryan, G.W., Langston, W.J., 1992. Bioavailability, accumulation and effects of heavy metals in sediments with special reference to United Kingdom estuaries: a review. Environ. Pollut. 76, 89-131.

Chan, T.Y., Lee, D.A., Lee, C.S., 2000. The first deep-sea hydrothermal animal reported from Taiwan: Shinkaia crosnieri Baba and Williams, 1998. Bull. Mar. Sci. 67, 799-804.

Charlou, J.L., Donval, J.P., 1993. Hydrothermal methane venting between $12^{\circ} \mathrm{N}$ and $26^{\circ} \mathrm{N}$ along the Mid-Atlantic Ridge. J. Geophys. Res. 98, 9625-9642.

Charlou, J.L., Bougault, H., Appriou, P., Jean-Baptiste, P., Etoubleau, J., Birolleau, A., 1991. Water column anomalies associated with hydrothermal activity between $11^{\circ} 40^{\prime}$ and $13^{\circ} \mathrm{N}$ on the East Pacific Rise: discrepancies between tracers. Deep-Sea Res. 38, 569-596.

Chen, Y.K., 1994. Dissolved methane in seawater off north Taiwan. Master's thesis, National Taiwan University. 62 pp. (in Chinese).

Chester, R., Thomas, A., Lin, F.J., Basaham, A.S., Jacinto, G., 1988. The solid state speciation of copper in surface water particulates and oceanic sediments. Mar. Chem. 24, 261-292.

Chester, R., Lin, F.J., Basaham, A.S., 1994. Trace metal solid state speciation changes associated with the down-column fluxes of the oceanic particulates. J. Geol. Soc. (Lond.) 151, $351-360$.

Chung, Y., Hung, G.W., 2000. Particulate fluxes and transports on the slope between the southern East China Sea and the South Okinawa Trough. Cont. Shelf Res. 20, 571-597.

Chung, S.L., Lo, C.H., Lee, T.Y., Lee, C.S., Shinjo, R., Ishizuka, H., Crawford, A.J., 1998. Magmatism and evolution of the Okinawa Trough (I). Workshop for Oceanographic Research Programs: Abstract, pp. 113-116. In Chinese.

Cowen, J.P., Massoth, G.J., Feely, R.A., 1990. Scavenging rates of dissolved manganese in a hydrothermal vent plume. Deep-Sea Res. 37, 1619-1637.

Cowen, J.P., Wen, X., Popp, B.N., 2002. Methane in aging hydrothermal plumes. Geochim. Cosmochim. Acta 66, 3563-3571.

Cruse, A.M., Seewald, J.S., 2001. Metal mobility in sediment-covered ridge-crest hydrothermal systems: experimental and theoretical constraints. Geochim. Cosmochim. Acta 65, 3233-3247.

Elbaz-Poulichet, F., Holliger, P., Huang, W.W., Martin, J.M., 1984. Lead cycling in estuaries, illustrated by the Gironde estuary, France. Nature 308, 409-414.

El Ghobary, H., Latouche, C., 1986. Distribution of certain metals in lithochemical fractions of sediments from the Arcachon Basin, southwest France: authigenic mineral formation and pollution. Chem. Geol. 54, 295-309.

Halbach, P., Nakamura, K., Wahsner, M., Lange, J., Sakai, H., Kaselitz, L., Hansen, R.D., Yamano, M., Post, J., Prause, B., Seifert, R., Michaelis, W., Teichmann, F., Kinoshita, M., Marten, A., Ishibashi, J., Czerwinski, S., Blum, N., 1989. Probable modern analogue of Kuroko-type massive sulfide deposits in the Okinawa Trough back-arc basin. Nature 338, 496-499.

Heussner, S., Ratli, C., Carbonne, J., 1990. The PPS 3 time-series sediment trap and the trap sample processing techniques used during the ECOMARGE experiment. Cont. Shelf Res. 10, 943-958.

Hirata, N., Kinoshita, H., Katao, H., Baba, H., Kaiho, Y., Koresawa, S., Ono, Y., Hayashi, K., 1991. Report on DELP 1988 cruises in the Okinawa Trough: Part III. Crustal structure of the 
southern Okinawa Trough. Bull. Earthq. Res. Inst. Univ. Tokyo 66, $91-150$.

Hsu, S.C., Lin, F.J., Jeng, W.L., Tang, T.Y., 1998. The effect of a cyclonic eddy on the distribution of lithogenic particles in the southern East China Sea. J. Mar. Res. 56, 813-832.

Hsu, S.C., Lin, F.J., Jeng, W.L., Tang, T.Y., 2003a. Spatial distributions of cadmium over a cyclonic eddy in the southern East China Sea. J. Mar. Syst. 39, 153-166.

Hsu, S.C., Lin, F.J., Chung, Y., Jeng, W.L., 2003b. Observed sediment fluxes of the southwesternmost Okinawa Trough enhanced by episodic events: flood runoff from northeastern Taiwan river and great earthquakes. Deep-Sea Res., Part I (in revision).

Ishibashi, J., Urabe, T., 1995. Hydrothermal activity related to arcbackarc magmatism in the Western Pacific. In: Taylor, B. (Ed.), Back-Arc Basins: Tectonic and Magmatism. Plenum, New York, pp. $451-495$.

Ishibashi, J., Wakita, H., Okamura, K., Nakayama, E., Feely, R.A., Lebon, G.T., Baker, E.T., Marumo, K., 1997. Hydrothermal methane and manganese variation in the plume over the superfast-spreading southern East Pacific Rise. Geochim. Cosmochim. Acta $61,485-500$.

Landing, W.M., Bruland, K.W., 1987. The contrasting biogeochemistry of iron and manganese in the Pacific Ocean. Geochim. Cosmochim. Acta 51, 29-43.

Landner, L., 1987. Speciation of Metals in Water, Sediment and Soil Systems. Proceedings of an International Workshop. SpringerVerlag, Berlin. 190 pp.

Lavelle, J.W., Cowen, J.P., Massoth, G.J., 1992. A model for the deposition of hydrothermal manganese near ridge crests. J. Geophys. Res. 97, 7413-7427.

Lee, C.S., 2002. Exploration of submarine hydrothermal springs. In: Liu, K.K., Liu, C.S. (Eds.), Ocean and Taiwan in the 21st Century. NCOR (National Center for Ocean Research), Taipei.

Lee, C.S., Shor, G.G., Bibee Jr., L.D., Lu, R.S., 1980. Okinawa Trough: origin of a back-arc basin. Mar. Geol. 35, 219-241.

Lee, C.S., Chung, S.L., Spot members, 1998. The southernmost part of the Okinawa Trough (SPOT): an active extension/collision/subduction area. EOS, Trans. Am. Geophys. Union 79, W109.

Lee, C.S., Chou, Y.H., Lian, S.C., Huang, K.L., 2000. The study of active submarine volcano geophysics of the southernmost Okinawa Trough. Workshop for Oceanographic Research Programs: Abstract, pp. 38-40. In Chinese.

Letouzey, J., Kimura, M., 1986. The Okinawa Trough: genesis of a back-arc basin developing along a continental margin. Geophysics 125, 209-230.

Li, Y.H., 1981. Ultimate removal mechanisms of elements from the ocean. Geochim. Cosmochim. Acta 45, 1659-1664.

Lin, F.J., Hsu, S.C., Jeng, W.L., 2000. Lead in the southern East China Sea. Mar. Environ. Res. 49, 329-342.

Liu, C.S., Liu, S.Y., Lallemand, S.E., Lundberg, N., Reed, D., 1998. Digital elevation model offshore Taiwan and its tectonic implications. Terres. Atmos. Ocean. Sci. 9, 705-738.

Lu, R.S., Pan, J.J., Lee, C.T., 1981. Heat flow of the southwestern Okinawa Trough. Earth Planet. Sci. Lett. 55, 299-310.

Noriki, S., Shiribiki, T., Yokomizo, H., Harada, K., Tsunogai, S., 1997. Copper and nickel in settling particle collected with sediment trap in the western North Pacific. Geochem. J. 31, $373-382$.

Nozaki, Y., Ikuta, N., Yashima, M., 1990. Unusually large ${ }^{210} \mathrm{Po}$ deficiencies relative to ${ }^{210} \mathrm{~Pb}$ in the Kuroshio Current of the East China and Philippine Seas. J. Geophys. Res. 95, 5321-5329.

O'Reilly Wiese, S.B., Emmerson, R.H.C., MacLeod, C.L., Lester, J.N., 1997. Trends in the solid phase partitioning of metals in the Thames Estuary sediments during recent decades. Estuaries 20, 494-503.

Pai, S.C., Lin, F.J., Tseng, C.M., Sheu, D.D., 1993. Optimization of heating programs of GFAAS for the determination of $\mathrm{Cd}, \mathrm{Cu}, \mathrm{Ni}$ and $\mathrm{Pb}$ in sediments using sequential extraction technique. Int. J. Environ. Anal. Chem. 50, 193-205.

Rajendran, A., Kumar, M.D., Bakker, J.F., 1992. Control of manganese and iron in Skagerrak sediments (northeastern North Sea). Chem. Geol. 98, 111-129.

Shaw, T.J., Gieskes, J.M., Jahnke, R.A., 1990. Early diagenesis in differing depositional environments: the response of transition metals in pore water. Geochim. Cosmochim. Acta 54, $1233-1246$.

Sherrell, R.M., Field, M.P., Ravizza, G., 1999. Uptake and fractionation of rare earth elements on hydrothermal plume particles at $945 \mathrm{~N}$, East Pacific Rise. Geochim. Cosmochim. Acta 63, $1709-1722$.

Shyu, C.T., Liu, C.S., 2001. Heat flow of the southwestern end of the Okinawa Trough. Terres. Atmos. Ocean. Sci. Suppl. Issue, 307-317.

Sibuet, J.C., Letouzey, J., Barbier, F., Charvet, J., Foucher, J.P., Hilde, T.W.C., Kimura, M., Chiao, L.Y., Marsset, B., Muller, C., Stephan, J.F., 1987. Back arc extension in the Okinawa Trough. J. Geophys. Res. 92, 14041-14063.

Sibuet, J.C., Hsu, S.K., Shyu, C.T., Liu, C.S., 1995. Structural and kinematic evaluations of the Okinawa Trough back-arc basin. In: Taylor, B. (Ed.), Back-Arc Basins: Tectonic and Magmatism. Plenum, New York, pp. 343-379.

Sibuet, J.C., Deffontaines, B., Hsu, S.K., Thareau, N., Le Formal, J.P., Liu, C.S., ACT party, 1998. Okinawa trough backarc basin: early tectonic and magmatic evolution. J. Geophy. Res. 103, 30245-30267.

Skei, J.M., Loring, D.H., Rantala, R.T.T., 1988. Partitioning and enrichment of trace metals in a sediment core from Framvaren, south Norway. Mar. Chem. 23, 269-281.

Taylor, S.R., 1964. Abundance of chemical elements in the continental crust: a new table. Geochim. Cosmochim. Acta 28, $1273-1285$.

Taylor, S.R., McLennan, S.M., 1985. The Continental Crust: Its Composition and Evolution. Blackwell, Oxford. 312 pp.

Tessier, A., Campbell, P.G.C., Bisson, M., 1979. Sequential extraction procedure for the speciation of particulate trace metals. Anal. Chem. 51, 844-851.

Tsunogai, U., Ishibashi, J., Wakita, H., Watanabe, K., Kajimura, S., Kanayama, S., Sakai, H., 1994. Peculiar features of Suiyo seamount hydrothermal fluids, Izu-Bonin arc: differences from subaerial volcanism. Earth Planet. Sci. Lett. 126, $289-301$.

Urabe, T., 1989. Mineralogical characteristics of the hydrothermal ore body at Izena Hole No. 1 in comparison with Kuroko depos- 
its. Proc. JAMSTEC Symp. Deep Sea Res., vol. 5, pp. 191-196. In Japanese with English abstract.

Welhan, J.A., 1988. Origins of methane in hydrothermal systems. Chem. Geol. 71, 183-198.

Welhan, J.A., Lupton, J.E., 1987. Light hydrocarbon gases in Guaymas Basin hydrothermal fluids: thermogenic versus abiogenic origin. Am. Assoc. Petrol. Geol. Bull. 71, 215-223.

Yamano, M., Uyeda, S., Foucher, J.P., Sibuet, J.C., 1989. Heat flow anomaly in the middle Okinawa Trough. Geophysics 159, 307-318.

You, C.F., Butterfield, D.A., Spcivack, A.J., Gieskes, J.M., Gamo, T., Cambell, A.J., 1994. Boron and halide systematics in submarine hydrothermal systems: effects of phase separation and sedimentary contributions. Earth Planet. Sci. Lett. 123, 227-238. 